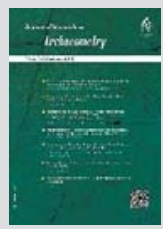

Original Paper

\title{
Correlation of the Epipaleolithic Period in the West-Central Zagros and North Zagros with Climatic Events after the Last Glacial Maximum (LGM)
}

\author{
Nemat Hariri ${ }^{1}$, Reza Rezalo ${ }^{2 *}$, Ardeshir JavanmardZadeh ${ }^{3}$, Saman Heydari-Guran ${ }^{4}$ \\ 1. Ph.D. Candidate in Archaeology, Mohaghegh Ardabili University, Ardabil, IRAN \\ 2. Prof., Department of Archaeology, Mohaghegh Ardabili University, Ardabil, IRAN \\ 3. Assistant Prof., Department of Archaeology, Mohaghegh Ardabili University, Ardabil, IRAN \\ 4. Stiftung Neanderthal Museum, Mettmann, Germany and Diyarmehr Institute for Palaeolithic \\ Research, Kermanshah, IRAN
}

Received: 23/04/2021

Accepted: 21/08/2021

\begin{abstract}
Up to now, two areas of northern and west-central Zagros Mountains (ZM) have produced better information concerning the development of techno-typology of lithic artefacts during the Epipaleolithic period (EP) compare to the other part of this region. Although several caves and rockshelters associated with EP deposits are found in this region (Map 1), but they were not subject to study for the relationship between climate effect on cultural developments like the neighbored area of Levant. this deficiency can be attributed to a) the low number of excavated sites, b) poor stratigraphic control, and c) the lack of a sufficient number of absolute dates. Recent absolute date achievements from the EP site of Palegawra cave [17]. locates on the northern ZM alongside Paleoclimatic reconstruction in Hashilan wetland [8] based on the palynological studies have improved our understanding from Epipaleolthic cultural and environmental events for the region.

Keywords: Epipaleolithic, Paleoclimatology, West-Central Zagros, Northern Zagros, Hashilan wetland.

\section{Introduction}

It's been proved that the final stage of the Pleistocene period (25 to $11.6 \mathrm{kyr} \mathrm{BP}$ ) in the Middle East coincides with the change of the Hunter-Gatherer system to food production ]1[. This cultural period is anthropologically known as Epipaleolithic. This period is dominated by lithic artefacts manufacturing of geometric and non-geometric microliths and combination tools [2,3]. This toolkit is being known as Zarzian culture since first found in the Zarzi cave located in the northern ZM. One of the earliest nuclei of the EP is the Fertile Crescent, which stretches from the eastern Mediterranean to the southern Anatolian Plateau, north of Mesopotamia and west of the ZM. Among these, the Levant region is the most important $[1,4]$.

Long-lasting researchers in the Levant region led to the identification of three phases: Early, Middle and Late for the EP (Fig 2). The first phase of EP in the Levant region is called the Nebekian and Kebaran culture, in which various forms of microliths are not geometric, the second is the Nebekian Geometric, and the latest culture is called Natufian, which coincides with the emergence of the Lunate [4].
\end{abstract}

*Corresponding Author: r_rezaloo@uma.ac.ir

Copyright $($ 2021, the Authors / This open-access article is published under the terms of the Creative Commons Attribution-NonCommercial 4.0 International License which permits Share (copy and redistribute the material in any medium or format) and Adapt (remix, transform, and build upon the material) under the Attribution-NonCommercial terms 
The initial period of the EP from 25 to $19 \mathrm{kyr}$ BP is almost simultaneous with the cold and dry event of the LGM, and the toolkit of Nebekian and Kebaran are related to this phase, which is associated with different types of non-geometric microliths (about 2 to $3 \mathrm{~mm}$ ) [1].

These studies have revealed that the middle of the EP (around 19 to $15 \mathrm{kyr} \mathrm{BP}$ ) is accompanied by gradual temperature going towards humid and warm conditions. However, This climactic event occurs just before a warm phase [26] known as the Oldest Dryas (Rasmussen et al., 2006). In this phase, the lithics of geometric Kebaran are associated with microliths such as trapezoids and triangles, as well as microburin technology. The tools of this period are considerably wider and vary from 5 to $9 \mathrm{~mm}$. At this phase, geometric microliths such as triangles, including scalene triangles, are significantly expanded in the geometric Kebaran industry [1]. This period was followed by a global warming oscillation called the Bølling-Allerod (B/A), which is comparable to the Holocene (Fig 1). The Late EP (15 to $11.6 \mathrm{kyr} \mathrm{BP}$ ) coincides with this warming period. This period is symmetrical with the two cultures of Natufian and Late Ramonian, which includes the third and last phase of the EP, and at this phase, the so-called Helwan lunates appear $[1,21]$. In contrast to the Levant region and some extent the Caucasus (Fig 2,3), our knowledge of the cultural changes of EP in the face of climate fluctuation for the ZM is very poor. The fact that we have not yet been able to reconstruct a partial picture of the temporal and cultural sequence related to climate change for this region is either because 1- Firstly the number of cultural studies for ZM is scant; 2- secondly our knowledge concerning climate records for the ZM is not that many details.

\section{Material and methods}

Despite the lack of strong information, here based on the recent accurate data obtained from reexcavation of the Palegawra Cave and Paleoclimate reconstruction from Hashilan wetland in central ZM, we are attempting to correlate the new climate data with human behaviour during EP for the north and the west-central ZM. As a result, due to the lack of absolute dating, it is only possible to establish a connection between cultural events and the end of the Pleistocene, based on the typology and technology of lithic tools. The common approach of researchers is that when geometrics are found in a site, they are attributed to the EP [56]. While these tools may not be geometric in nature, they fall into the EP, often leading to a strategic error that documents such tools as the late Upper Palaeolithic. For example, in open-air sites such as Turkaka and Kowri khan, which were surveyed by the Iraq-Jarmo project, the absence of geometrics in the mentioned collection suggests that they may be before Zarzi and Palegawra sites [17].

\section{Discussion and Result}

The excavation of the Palegawra Cave has partially compensated for the weakness of the data, as the second and third phases of the cave cover the period 19.6 to $13 \mathrm{kyr}$ BP. Finally, phase one, which includes the LGM, is still shrouded in mystery. According to the data obtained from the Caucasus, available data it can be acknowledged that the ZM is more in line with this region than the Levant because the EP sites in this region date back to $18 \mathrm{kyr}$ BP. Furthermore, the dating of Palegawra Cave, indicates that the beginning of the EP starts around $19.6 \mathrm{kyr}$ BP and the beginning of the Zarzi culture in the northwest of the ZM approximately $15 \mathrm{kyr} \mathrm{BP}$, although some researchers suggest the beginning as $17 \mathrm{kyr}$ BP [17]. it seems that the improvement of the climatic situation at the beginning of the late glacial period has led to changes in the technology of EP lithic tools, settlement patterns and subsistence. The new data Palegawra, such as cultural materials and dating, disprove past definitions of resource scarcity, unfavourable climate, and cultural and geographical isolation of EP settlements in the northern ZM, and can be used as a model for the reconstruction of EP communities in other parts of the ZM, especially the west-central ZM [17]. However, due to the different settlement patterns in the Upper Paleolithic in the Southern ZM, it can be expected that this difference in the following periods (EP) has also persisted. Due to the high richness of the sites of different Paleolithic periods, the Kermanshah region in the west-central ZM [12] and the climatic data obtained from it, excavation in this region can answer key questions regarding EP settlements and their adaptation to climatic periods. 


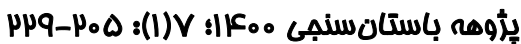

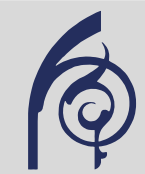

*

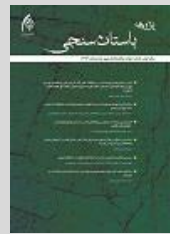

دقالم يَّهوشى

\section{$\underbrace{}_{\text {CrossMark }}$

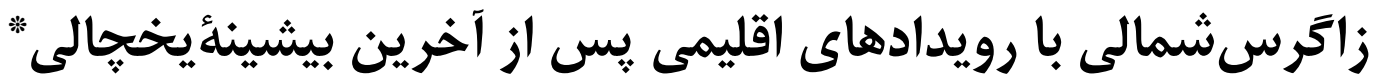

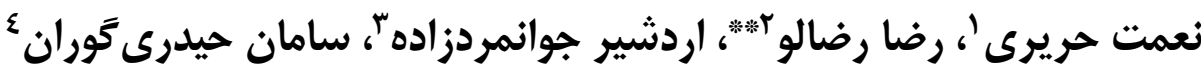

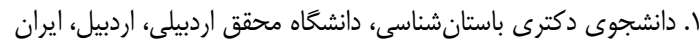

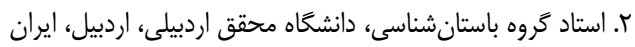

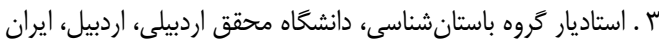

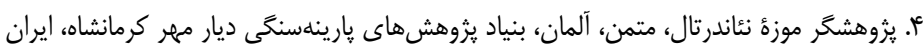

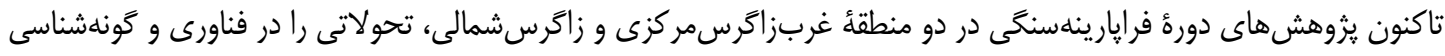

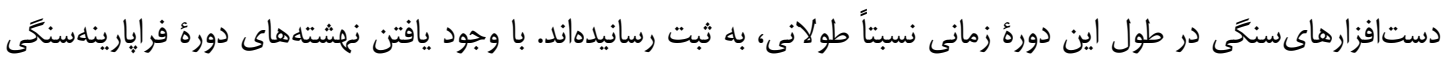

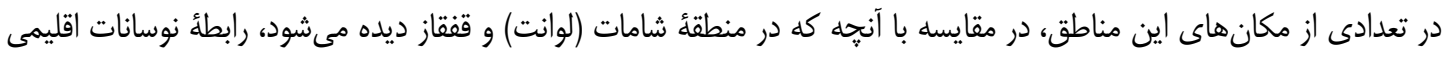

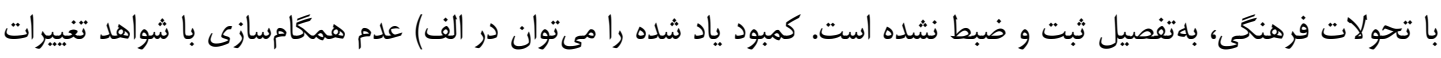

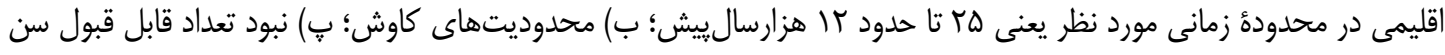

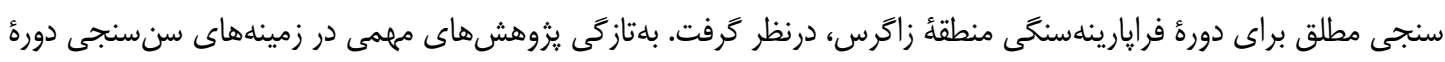

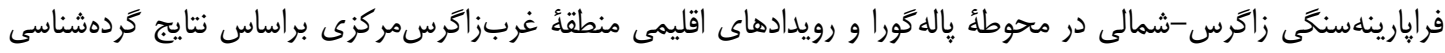

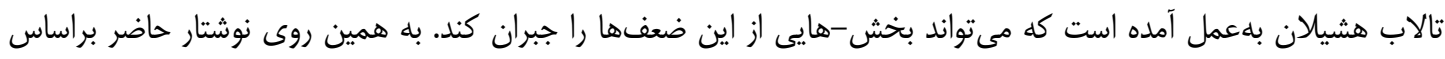

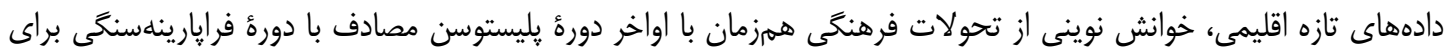
اين منطقه ارائه كرده است.

\section{وازَّان كليدى: فرايارينهسنگى، ديريناقليه، غربزاكرسمركزى، زاگرسشمالى، تالابهشيلان}

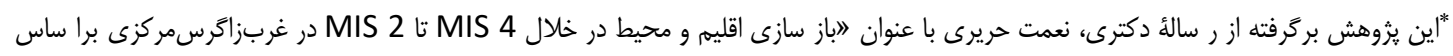

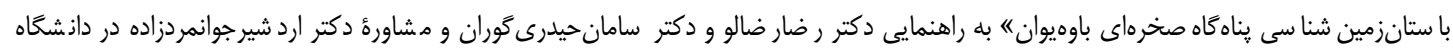
محقق اردبيلى است. ** *ويسنده مسئول مكاتبات: ايران، اردبيل، خيابان دانشكاه، دانشكاه محقق اردبيلى، دانشكده علوم اجتماعى، گروه باستانشناسى.

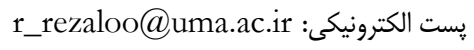

(C) حق نشر متعلق به نويسنده(ًان) است و نويسنده تحت مجوز Creative Commons Attribution License به مجله اجازه مى دهد مقاله خاب شده را با ديخران به اشتراك بكذارد منوط بر اينكه حقوق مؤلف اثر حفظ و بهن انتشار اوليه مقاله در اين مجله اشاره شود. 
ميانى هـ ستيه. بهاين ترتيب كه ريز ابزارهاى سنكى از حالت نازك، باريك، كولدار و غيرهند سى به به ابزارهاى

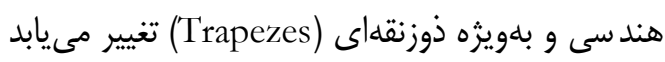

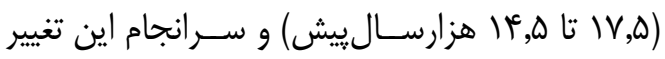
بلهسمت دستافزارهاى هلالى در اواخر فرايارينهسنگى متمايل مى شود [4].

\section{I- (. يرسشها و فرضيات يزوهش}

در مقايسـه با يثوهشهاى انجام شــده در شـامات و

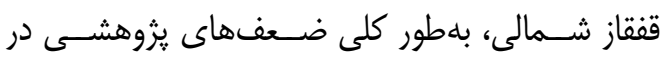

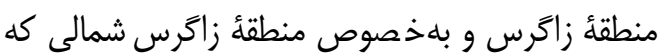

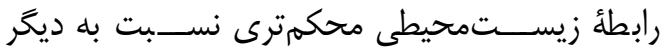

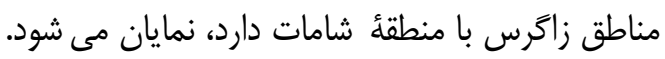

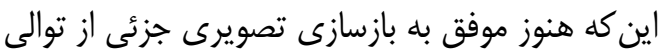

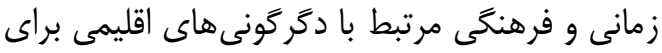

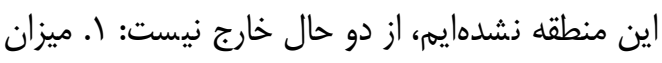

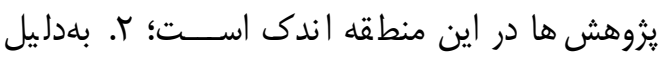
شرايط اقليمى منطقة زاكرس، تمامى زير دورههاى ياد

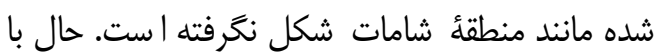

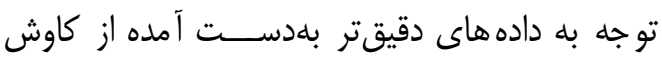

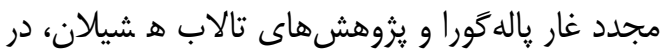
اين يزوهش بنا است كه همخامسازى دادههاى اقليمى بادي

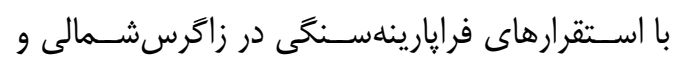
غربزاگرسمركزى ارزيابى شود.

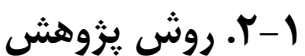

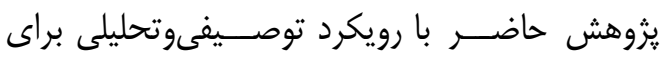

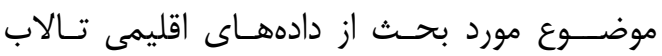

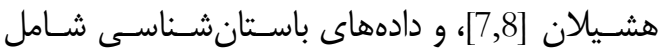

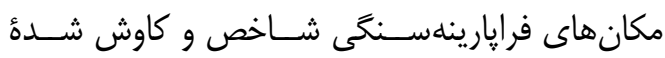
منطقعُ غربزاكرسمركزى (كر مانشــاه و خرمآ باد)

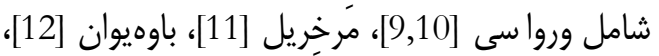

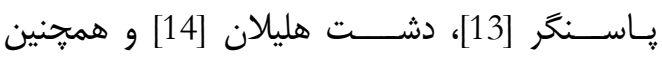

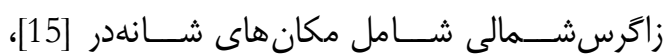

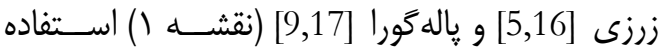

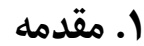

از نظر ان سان شنا سى مرحلةً نهايى دورة پِلي ستو سن،

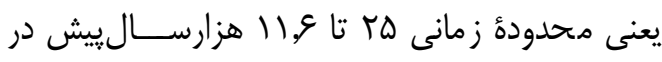

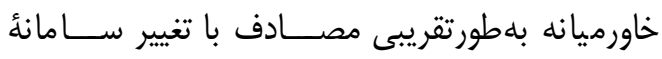
شـارورزى و كردآورى (Hunter-Gatherer) غذا به

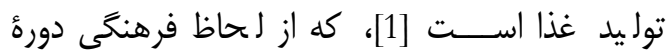

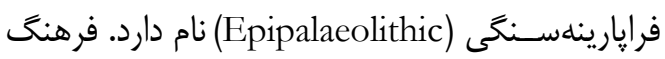

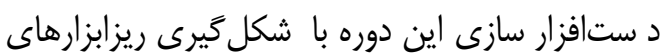

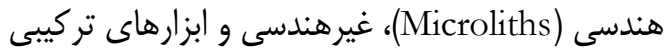

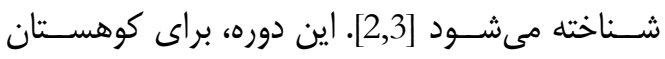
زاگرس تحت عنوان فرهنَ زرزى شناخته شده است،

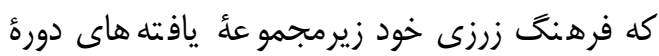

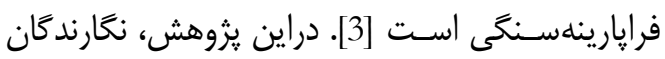

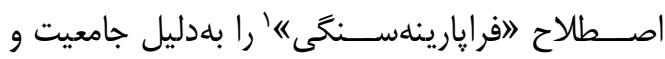

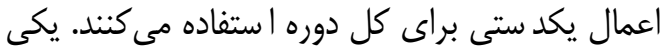

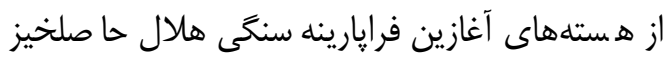

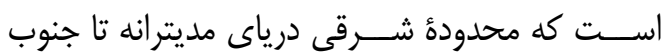

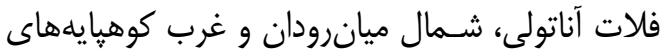

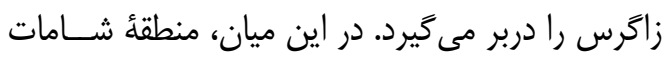

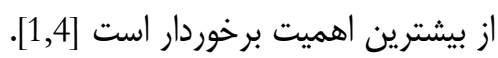

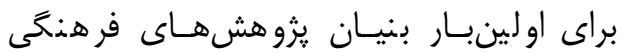

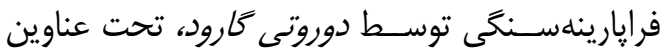

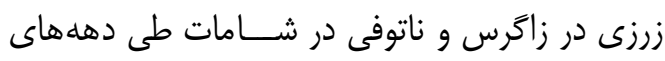

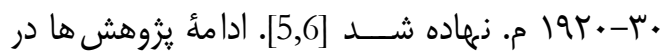

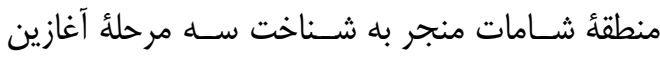

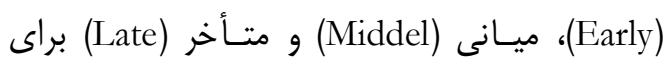

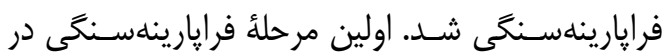

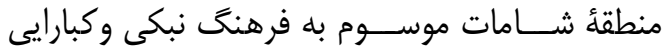
مختلف (Nebekian and Kebaran) مختلف ريزابزار هاى غيرهندســـ وجود دارد؛ دومين

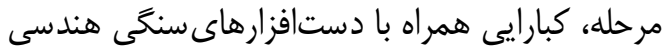
و آخرين فرهنغ، ناتوفى (Geometric Kebaran)

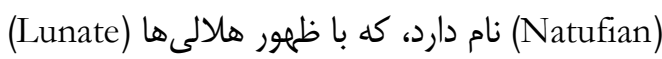

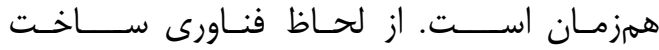

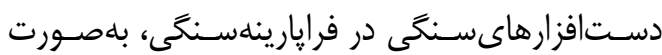

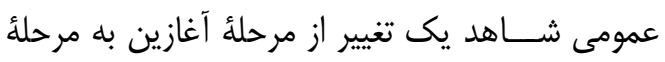


شـامل درياس كهن (Oldest Dryas)، درياس قديم

و درياس جوان (Older Drayas) اســت. اين نوســانات بر رفتار جوامع انســانى اواخر يلي ستو سن تأثير مـ ستقيمى بر جاى كذا شته ا ست. از

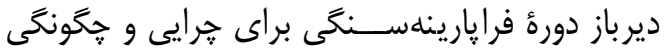

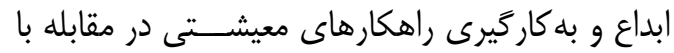

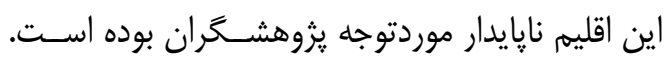
مدارك با ستان شنا سى حاكى از اين ا ست كه ميزان

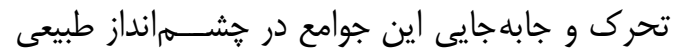

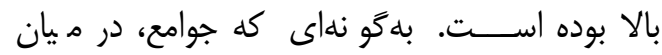

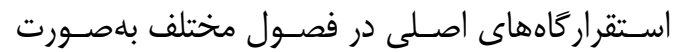
مداوم در رفتوآمد بودهاند [1].
مى كند و نتايج آنها با دو منطقعُ شـــامات-1,4,18 [20 و قفقازشمالى [21] مقايسه مى مودد.

\section{r. دوره فرايارينهسنَى و اوضاع اقليمى}

اواخر يليستوسن همزمان با تغييرات اقليمى ير نوسان

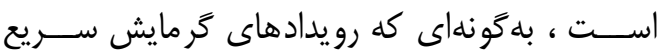
D-O: Dansgaard-Oeschger) دنســحرد

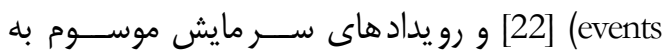
هاينريش اســتديال (Heinrich Stadial Events) بلهـــورت مداوم رخ داده اســت. بـه عبارتى ديخر رويدادهاى گرماي شى مـ شخ ماً شامل بولينگ- آلرود

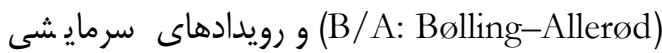

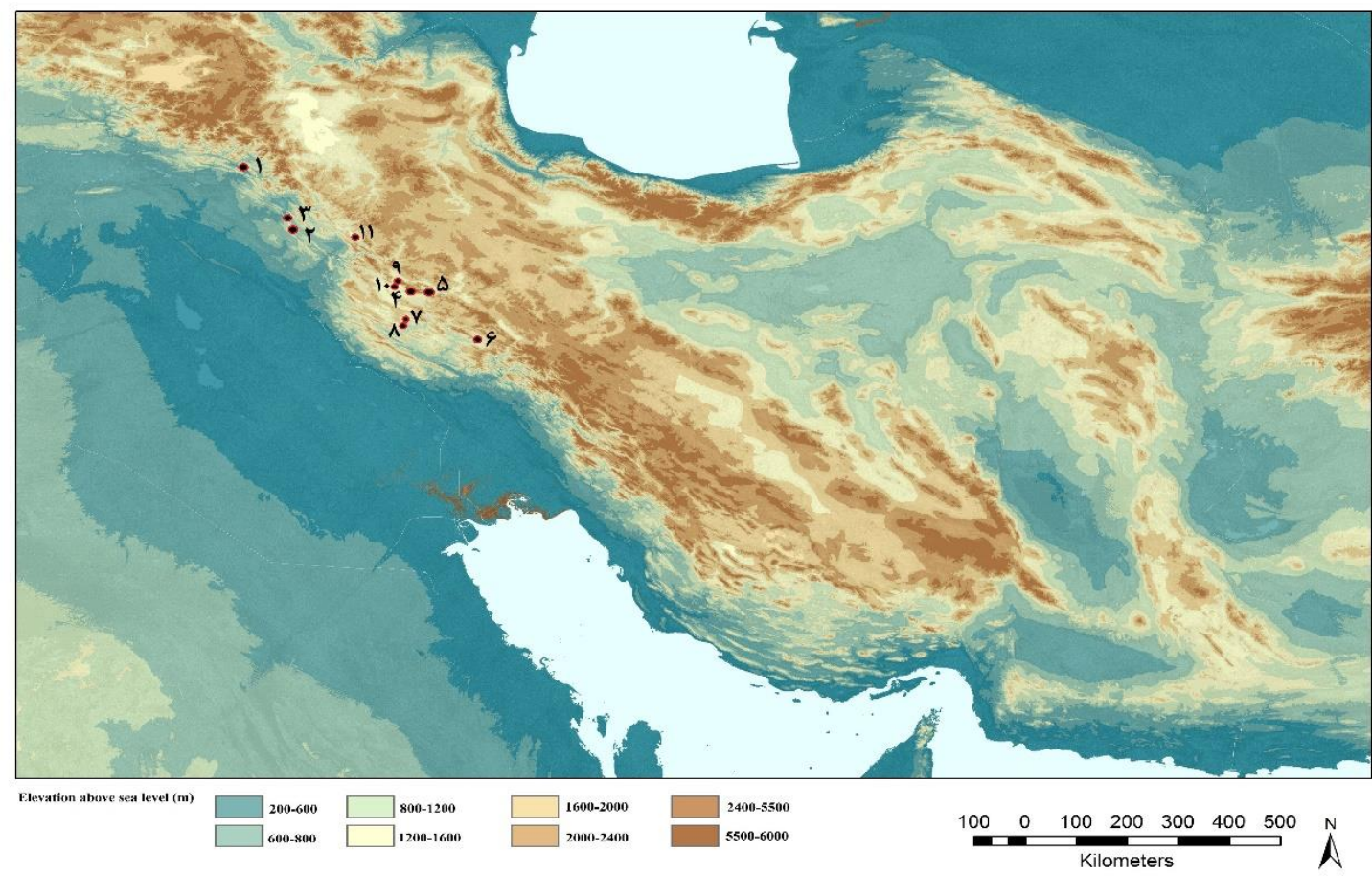

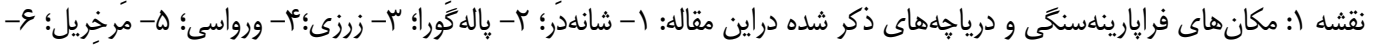

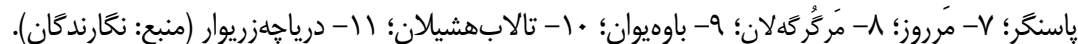

Map 1: Map showing the location of sites mentioned in the paper. 1- Shanidar 2- Palegawra 3- Zarzi 4- Warwasi 5- Ghare Khar 6- Pasangar 7- Mar Ruz 8- Mar Gorgalan 9- Bawa Yawan 10- Hashilan wetland 11- Zeribar lake (authors).

سr هزار سال ييش كه با آخرين بيشينأيخهالى ( Last (Glacial Maximum همزمان است، نسبت مى دهند.

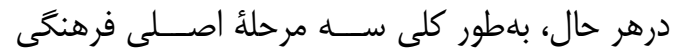

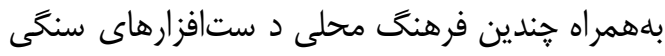

تاريخ گذارى شـــروع دوره فرايارينهســـــى در منطقة

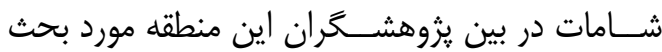

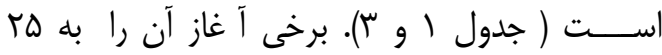
هزارســال ييش و برخى ديخر نيز آغاز اين دوره را به إنه

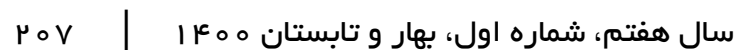


عريضتر و از هنج تا نُه ميلى متر متغير هـ ستند. در اين

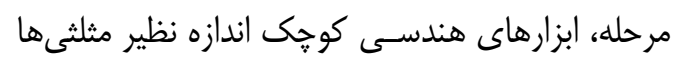

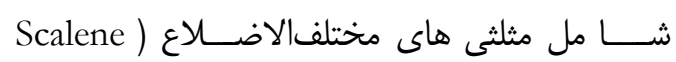
(Triangle ملاحظهاى مى يابند [1]. بعد از اين دوره يكى نوســان

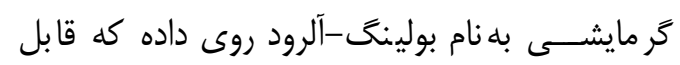
مقايسه با دوره هولو سن است. فرإيارينه سنحى متأخر

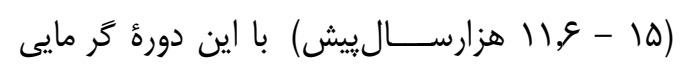
همزمان است (شكل (). اين دوره شامل زيردورههاى

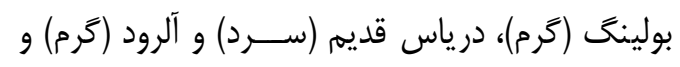

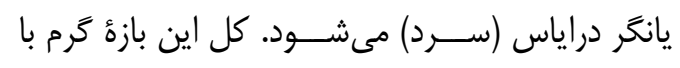

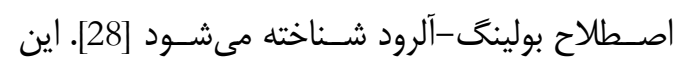

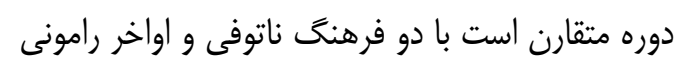
كــهـ ســومين و آخر ين فــاز (Late Ramonian)

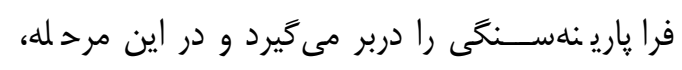
هالالى هاى موســـوم به هلوانى (Helwan lunates) ظاهر مىشوند [1,21].
درمنطقع شامات يِ شنهاد شده است [1,2,4,24,25].

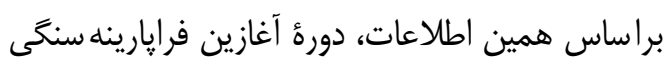
ها الى 19 هزارسـال ييش كمابيش همزمان با آخرين بيشينأيخجالى است و صنعت دستافز الف ارسازى موسوم

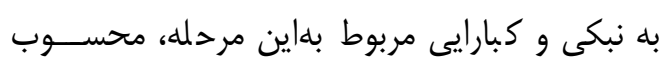

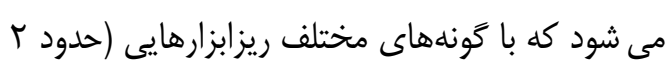

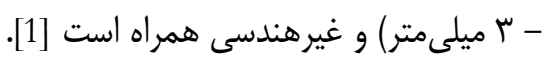

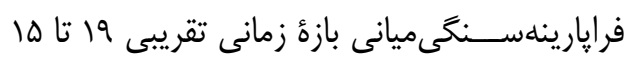

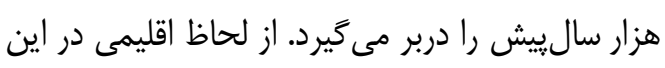

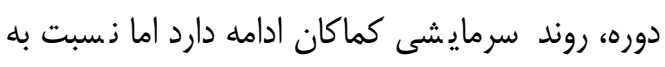

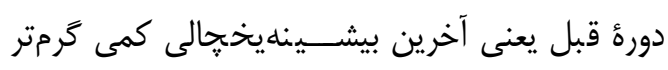

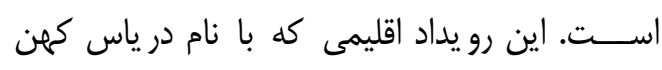
شناخته مى شود [21,27]، در ست ييش از يك مرحلئ كرم رخ مى دهد [26]. صنعت دستافزار سازى موسوم به هندسـىهاى كبارايى مربوط بهاين مرحله بوده كه دهن

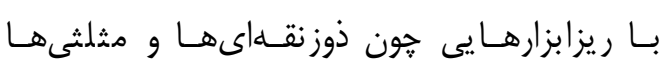
و همجنين فناورى ريزاسكنه همراه بوده دون (Triangles)

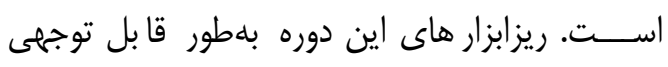

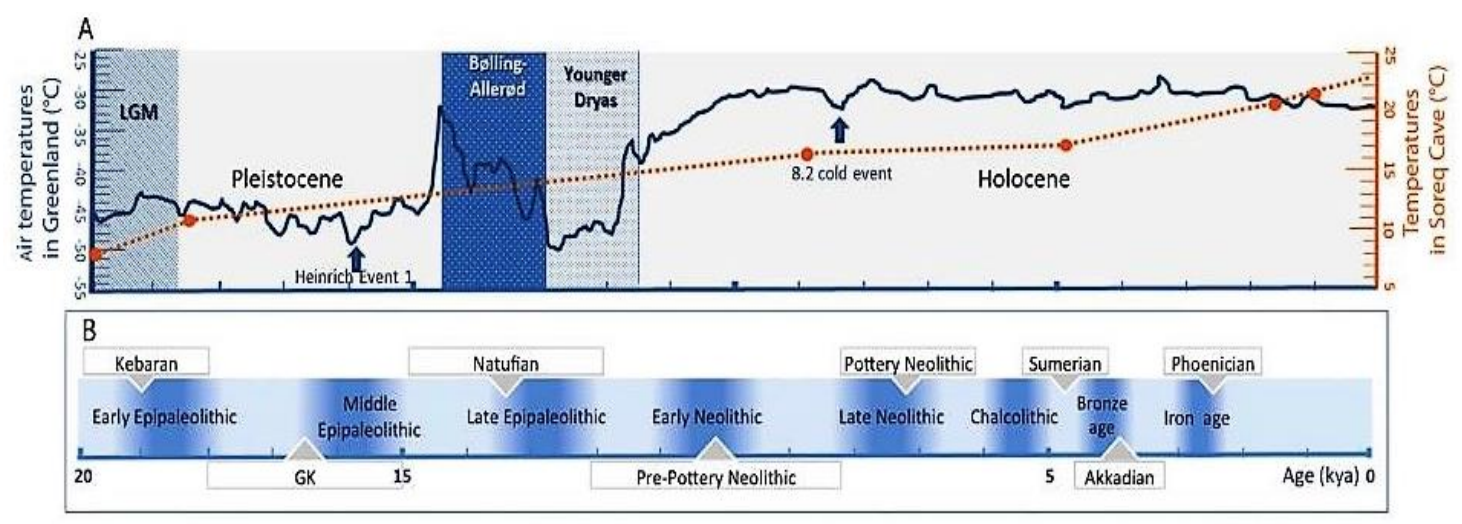

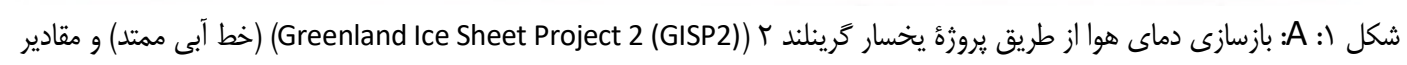

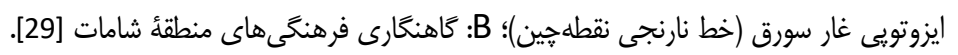

Fig 1. A: Reconstructed air temperatures from the GISP 2 Ice core in Greenland (blue solid line); Isotope values from Soreq cave, Israel (orange dotted line). B: Chronology of cultural entities in the Levant [29].

اين دوره، علاوهبر كشــف زير دوره هايى براى اين

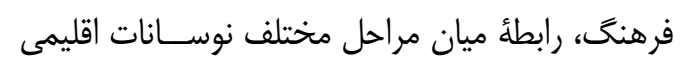

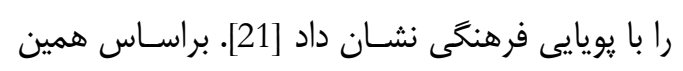

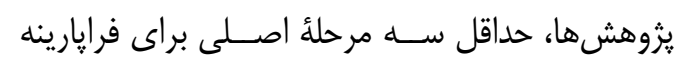

يُوهشهاى دامنهدار اخير در منطقعَ قفقاز در رابطه با

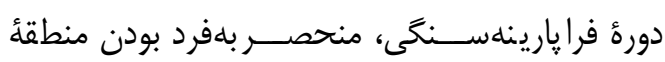

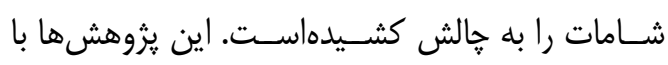
مرور و تحليل مواد فرهنگى و سن سنجى استقرارهاى 
يوشـش جنَلم و اقليم مرطوب و گرم همراه اســت.

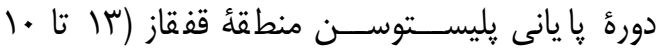

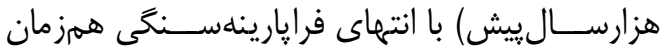

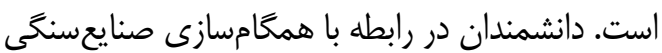
فرايارينه سنگى قفقاز شمالى با شرايط زيستمحيطى بلاين نتيججه رســيدهاند ( جدول r) كه در آخرين بيشينهُيخهالى، صنايع سنگى با كسترش بسيار فراوان ريزتيغهها و بلويزه ريزتيغههاى كولدار همراه بوده كه بهطور مشخص ريشه در دورة يارينهسنَّىنوين داشته

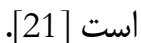

سنَّى يِشنهاد داده شده است. دورة آغازين با سن تقويمى هr تا م| هزار سالييش كه با دورهٔ بسيار سرد

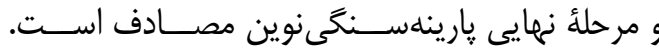

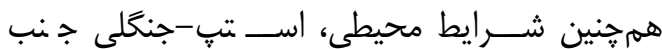

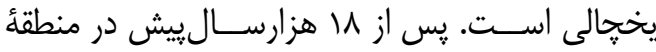
قفقاز با فرهنَ جديد فرايارينه سنگَى مواجه هـ ستيه.

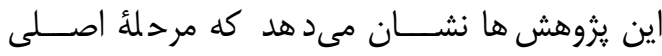

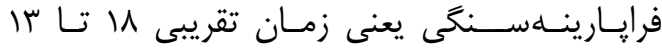
هزار ساليش ييش يك دورة زي ستمحيطى بـ سيار ايدهآل مح سوب مى شود و بي شتر محوطههاى منطقة قفقاز

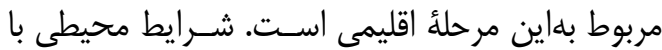

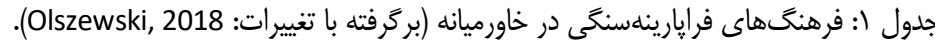

Table 1. Middle Eastern Epipalaeolithic archaeological cultures (Modified after Olszewski, 2018).

\begin{tabular}{|c|c|c|c|c|c|c|}
\hline \multirow{2}{*}{$\begin{array}{l}\text { Zagros } \\
\text { Zاگرس }\end{array}$} & \multicolumn{4}{|c|}{$\begin{array}{c}\text { منطقهُ شامات } \\
\text { Levant }\end{array}$} & \multirow{2}{*}{$\begin{array}{l}\text { مرحله } \\
\text { Phase }\end{array}$} & \multirow{2}{*}{$\begin{array}{c}\text { سال تقويمى } \\
\text { (ييش از حال } \\
\text { Cal. Years } \\
\text { BP }\end{array}$} \\
\hline & & 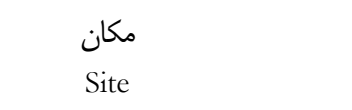 & & فرهنً & & \\
\hline \multirow[b]{2}{*}{$\begin{array}{l}\text { (؟) } \\
\text { Zarizi? }\end{array}$} & & $\begin{array}{l}\text { Uwaynid } 14 \text { وادى مادماق، Wadi Madamagh;KPS-75 } \\
\text { Wadi }\end{array}$ & & $\begin{array}{c}\text { نبكى } \\
\text { Nebekian }\end{array}$ & \multirow{2}{*}{$\begin{array}{l}\text { فرآغارينهسنگ آغازين } \\
\text { Early } \\
\text { Epipleolithic }\end{array}$} & \multirow[b]{2}{*}{$25000-19000$} \\
\hline & $\begin{array}{c}\text { القصين } \\
\text { Ayn } \\
\text { Qasiyya }\end{array}$ & 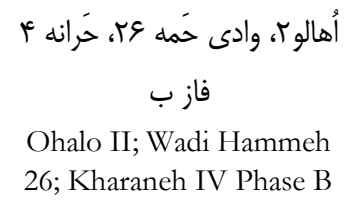 & Qalkhan & $\begin{array}{c}\text { كبارايى } \\
\text { Kebaran }\end{array}$ & & \\
\hline $\begin{array}{l}\text { (؟) } \\
\text { Zarizi? }\end{array}$ & \multicolumn{2}{|c|}{ 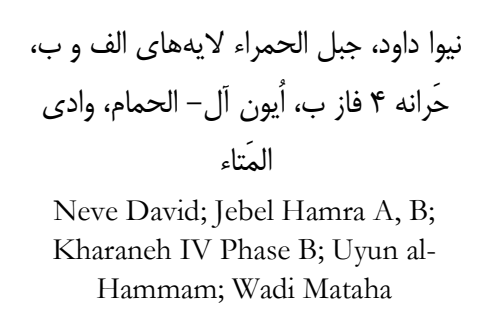 } & $\begin{array}{c}\text { هُمَان } \\
\text { Hamran } \\
\text { موشابى } 1 \text { اوايل رامونى } \\
\text { Mushabian } \\
\text { Early } \\
\text { Ramonian }\end{array}$ & $\begin{array}{l}\text { هندسى هاى } \\
\text { كبارايى } \\
\text { Geometric } \\
\text { Kebaran }\end{array}$ & $\begin{array}{c}\text { فرايارينdسنگگ } \\
\text { ميانىى } \\
\text { Middle } \\
\text { Epipaleolithic }\end{array}$ & $19000-15000$ \\
\hline \multirow{3}{*}{$\begin{array}{l}\text { Zjjj } \\
\text { Zarizi }\end{array}$} & \multirow{3}{*}{\multicolumn{2}{|c|}{ 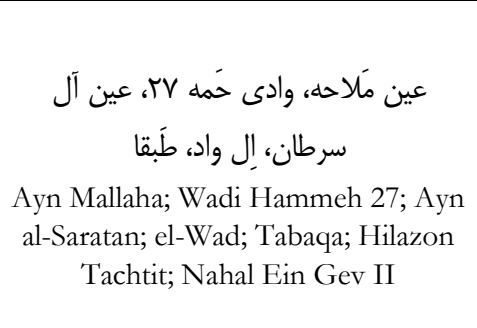 }} & \multirow{3}{*}{$\begin{array}{c}\text { رامونى } \\
\text { متأخرَ } \\
\text { Late } \\
\text { Ramonian } \\
\text { Hريفىى } \\
\text { Harifian }\end{array}$} & $\begin{array}{c}\text { اوايل ناتوفى } \\
\text { Early Natufian }\end{array}$ & \multirow{3}{*}{$\begin{array}{c}\text { فرايارينهسنگیى } \\
\text { متأخر } \\
\text { Late } \\
\text { Epipaleolithic }\end{array}$} & \multirow{3}{*}{$15000-11600$} \\
\hline & & & & $\begin{array}{c}\text { Late Natufian } \\
\text { اواخر ناتوفى }\end{array}$ & & \\
\hline & & & & $\begin{array}{c}\text { ناتوفى ^ايانى } \\
\text { Final Natufian }\end{array}$ & & \\
\hline
\end{tabular}


جدول ז: همكامسازى دادهاى اقليمى و محيطى با مكانهاى فرإيارينهسنگى قفقاز شمالى [21].

Table 3. Correlation of environmental and climate data for the Epipaleolithic sites in the Northern Caucasus [21].

\begin{tabular}{|c|c|c|c|c|c|c|}
\hline 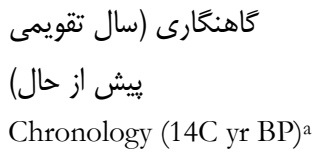 & $\begin{array}{l}\quad \text { كوبز } 1 \\
\text { Gubs } 1 \\
\text { Rockshelter }\end{array}$ & $\begin{array}{l}\quad \text { مزمايسكايا } \\
\text { Mezmaiskaya } \\
\text { Cave }\end{array}$ & $\begin{array}{l}\text { كازووسكايا } \\
\text { Kasojskaya } \\
\text { Cave }\end{array}$ & $\begin{array}{c}\text { سداناى (كوبزV) } \\
\text { Satanai } \\
\text { Rockshelter }\end{array}$ & $\begin{array}{l}\text { جى } \\
\text { Chygai } \\
\text { Rockshelter }\end{array}$ & $\begin{array}{l}\text { بادينكو } \\
\text { Badinoko } \\
\text { Rockshelter }\end{array}$ \\
\hline $\begin{array}{l}\text { The Holocene } \\
\text { هولوسن } \\
\text { 8000-10,000 Boreal } \\
\text { and Preborea }\end{array}$ & & $\begin{array}{l}\text { Layer } 1-2 \\
8680 \pm 100 \\
\text { Layer } 1-2 \mathrm{~A} \\
8720 \pm 70 \\
\text { warm and dry }\end{array}$ & Horizon 1 & $\begin{array}{l}\text { Horizons } 1 \text { - } \\
2\end{array}$ & $\begin{array}{l}\text { Layers 3-5 } \\
\text { goat }\end{array}$ & \\
\hline 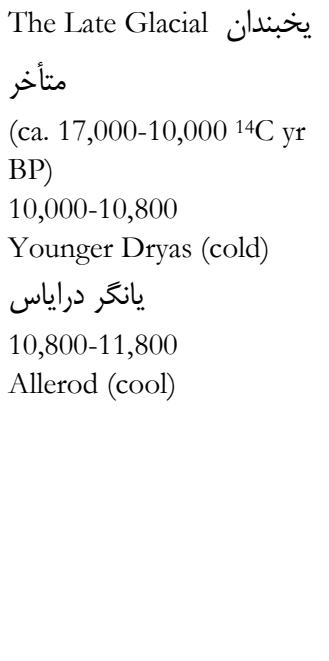 & & Brechee level & $\begin{array}{l}\text { Slabs level } \\
\text { Horizon } 3 \\
10,550 \pm 130 \\
\text { Horizon } 4 \\
11,000 \pm 150 \\
\text { Equus, } \\
\text { Bison, } \\
\text { Cervus }\end{array}$ & $\begin{array}{l}\text { Collapsed } \\
\text { level } \\
\text { cold steppe } \\
\text { Horizon } 2-3 \\
11,200 \pm 110 \\
\text { Horizon } 3 \\
11,140 \pm 100 \\
\text { Horizon } 4 \\
11,200 \pm 130 \\
\text { Equus, } \\
\text { Bison, } \\
\text { Capra, Sus } \\
\text { scrofa, } \\
\text { Capreolus, } \\
\text { Helixs } \\
\text { shells cold } \\
\text { steppe }\end{array}$ & $\begin{array}{l}\text { Layer } 7 \\
\text { Layers 6-8 } \\
\text { Cricetus } \\
\text { cricetus } \\
\text { (ordinary } \\
\text { hamster) } \\
\text { steppe } \\
\text { climate }\end{array}$ & \\
\hline 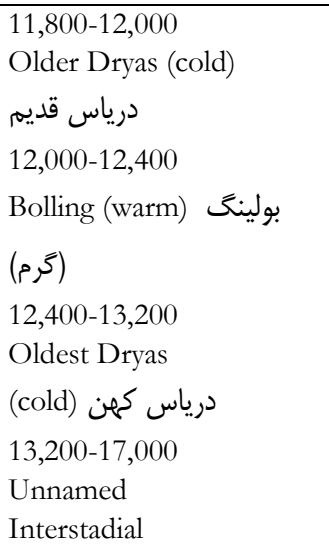 & $\begin{array}{l}\text { Layer } 2 \\
\text { Bison, } \\
\text { Capra/Ovis } \\
\text { Layer } 3 \\
\text { deciduous } \\
\text { woods, } \\
\text { warm and } \\
\text { humid }\end{array}$ & \multirow{2}{*}{$\begin{array}{l}\text { Layer 1-3 } \\
\text { deciduous } \\
\text { woods, warm } \\
\text { Bos/Bison, } \\
\text { Sus scrofa, } \\
\text { Cervus } \\
\text { elaphus, } \\
\text { Capra, } \\
\text { Capreolus } \\
12,960 \pm 60 \\
13,860 \pm 70 \\
\text { Layer } 1 \mathrm{e} 4 \\
\text { deciduous } \\
\text { woods, most } \\
\text { favorable } \\
\text { conditions } \\
16,260 \pm 100 \\
21,050 \pm 110 / 1 \\
20\end{array}$} & \multirow[t]{2}{*}{$\begin{array}{l}\text { Horizon } 5 \\
14,050 \pm 100\end{array}$} & & $\begin{array}{l}\text { Layer } 9 \\
\text { Sus scrofa, } \\
\text { Emys } \\
\text { (Marsh } \\
\text { turtle) } \\
13,250 \pm 500\end{array}$ & $\begin{array}{l}\text { Horizon } 5 \\
\text { Helix shells } \\
\text { middle level } \\
12,635 \pm 150 \\
\text { lower level } \\
13,990 \pm 340\end{array}$ \\
\hline $\begin{array}{l}\text { آخرين بيشينه يخخال } \\
\text { The Last Glacial Maximun } \\
\text { 17,000 }{ }^{14} \text { C yr BP) } \\
\text { 4-7 periglacial } \\
\text { forest-steppe }\end{array}$ & $\begin{array}{r}\text { (ca. 23,000- } \\
\text { Layers }\end{array}$ & & & & & \\
\hline
\end{tabular}




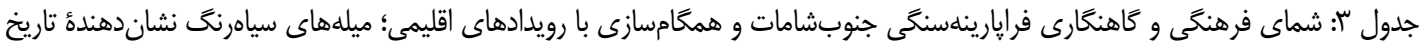

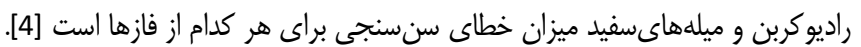

Table 3: Cultural-chronological scheme for the EP of the southern Levant alongside major climate events. The bars for each phase of the EP represent calibrated radiocarbon dates (black) along with associated errors (white) [4].

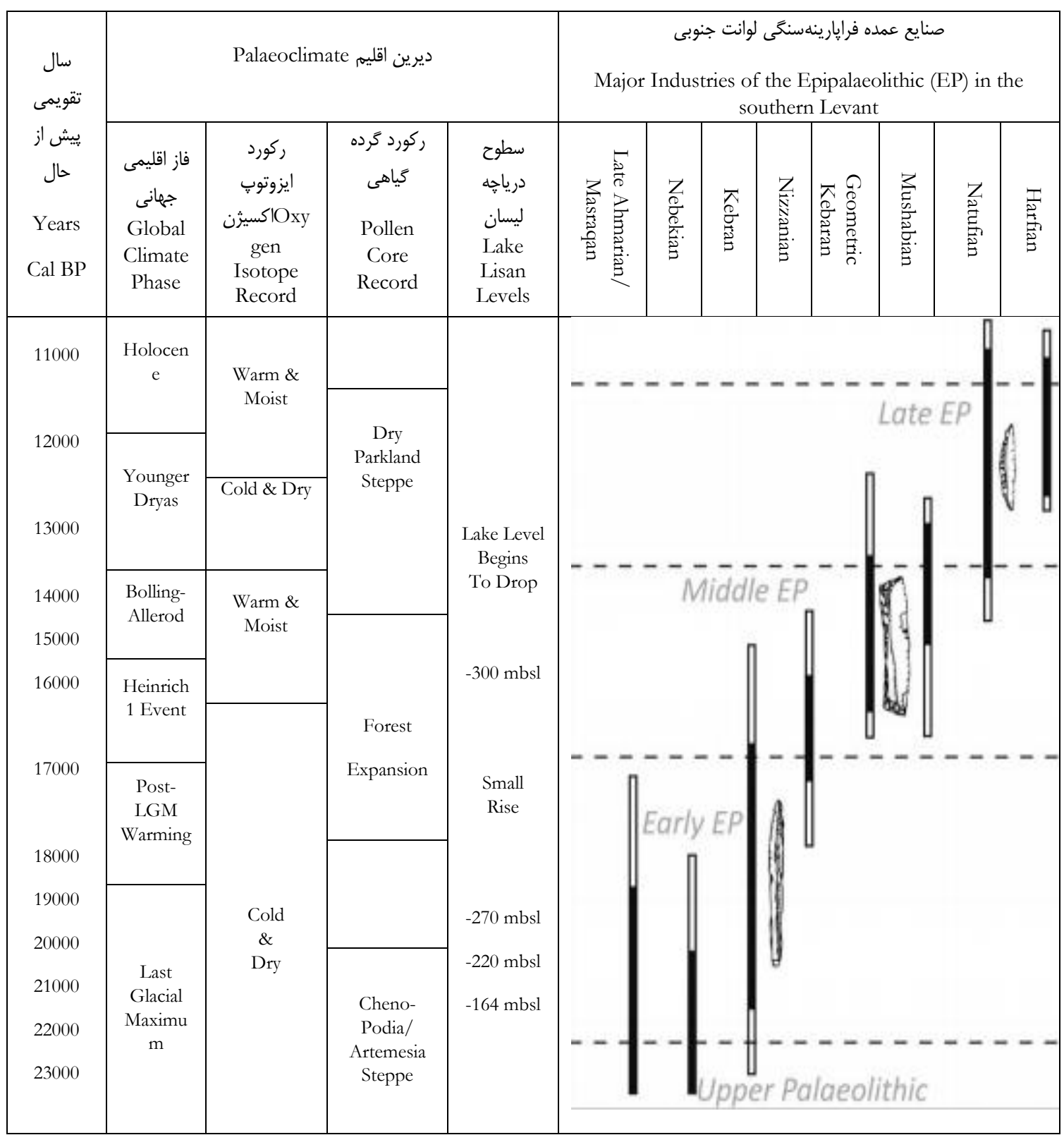

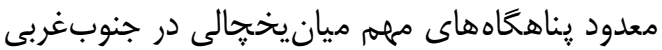

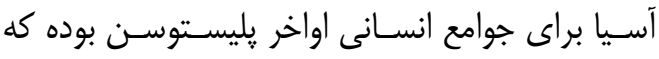

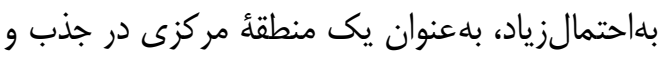

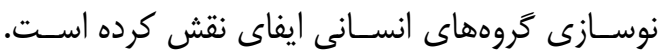

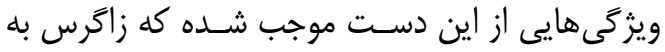

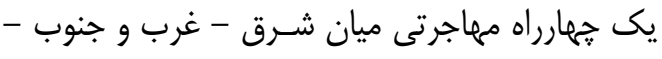

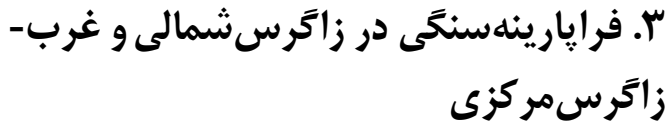

زاترس از دير باز بلعنوان يك جزيرهُ مرطوب كه در

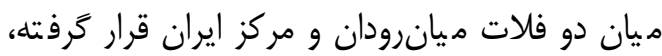

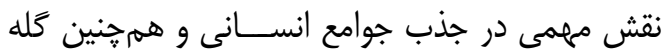

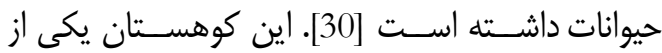

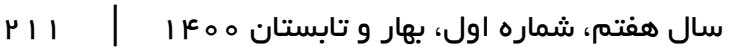




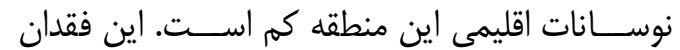

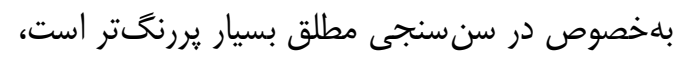

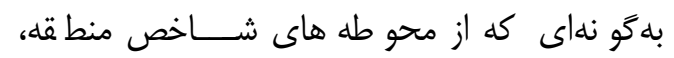

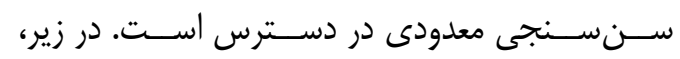

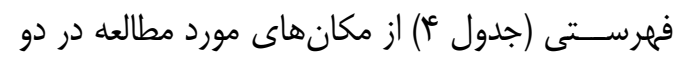

منطقهُ فوق آورده شده است.

$$
\begin{aligned}
& \text { شمال تبديل شود [31]. علاوهبر اين، زاكرس بهعنوان }
\end{aligned}
$$

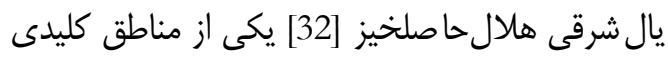

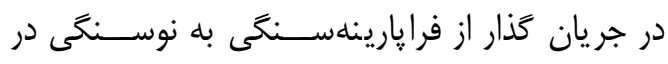

$$
\begin{aligned}
& \text { مقياس جهانى محسوب مى شود. با اين و صف، دانش }
\end{aligned}
$$

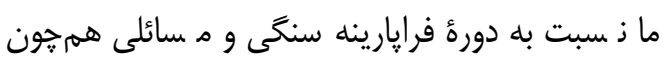

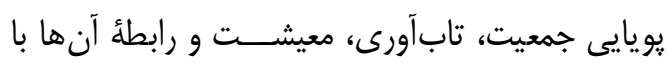

جدول fا: فهرست محوطههاى فرايارينهسنگى در اين ثزوهش و مشخصات آنها.

Table 4. List of Epipaleolithic sites in this study and their characteristics.

\begin{tabular}{|c|c|c|c|c|c|}
\hline $\begin{array}{l}\text { نام يزوهشگَر و منبع } \\
\text { Reference }\end{array}$ & قدمت & $\begin{array}{c}\text { نوع يثوهش } \\
\text { Research Type }\end{array}$ & $\begin{array}{c}\text { سطح دريا } \\
\text { asl }\end{array}$ & $\begin{array}{c}\text { مكان } \\
\text { Location }\end{array}$ & $\begin{array}{l}\text { نام محوطه } \\
\text { Site }\end{array}$ \\
\hline سولكى (1963 & $\begin{array}{c}\text { فرايارينهسنگى متأخر } \\
\text { Late } \\
\text { Epipaleolithic }\end{array}$ & $\begin{array}{c}\text { كاوش } \\
\text { Excavate } \\
\text { 1951, 1951, } \\
1956-57,1960\end{array}$ & $765 \mathrm{~m}$ & $\begin{array}{c}\text { كردستان عرسمالى؛ اربيل؛ } \\
\text { North Zagros; Erbil; } \\
\text { Iraqi Kurdistan } \\
\end{array}$ & $\begin{array}{c}\text { غار شانهدرَ } \\
\text { Shanidar Cave }\end{array}$ \\
\hline $\begin{array}{c}\text { گارود؛ وحيدا } \\
\text { Garrod, 1930; ) } \\
\text { (Wahida, } 1971\end{array}$ & $\begin{array}{c}\text { فرايارينهسنگى متأخر } \\
\text { Late } \\
\text { Epipaleolithic }\end{array}$ & $\begin{array}{c}\text { كاوش } \\
\text { Excavate } \\
1971,1928\end{array}$ & $760 \mathrm{~m}$ & زاكرس شرالى؛ سليمانيه؛ & $\begin{array}{c}\text { غار زرزى } \\
\text { Zarzi } \\
\text { Cave }\end{array}$ \\
\hline $\begin{array}{c}\text { بريدوود؛ اسوتى و همكاران } \\
\text { Asouti et al., ) } \\
\text { 2020; Braidwood } \\
\text { (and Howe, } 1960\end{array}$ & $\begin{array}{c}\text { فرايارينdسنگى متأخر، } \\
\text { Late, Middle } \\
\text { Epipaleolithic }\end{array}$ & $\begin{array}{c}\text { كاوش } \\
\text { Excavate } \\
\text { 1955, 1951, } \\
\text { 2016-2017 }\end{array}$ & $990 \mathrm{~m}$ & 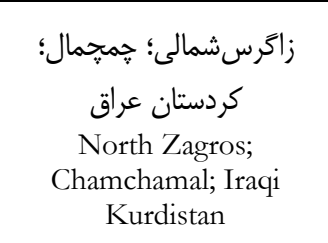 & $\begin{array}{l}\text { غار ياله }{ }^{\prime} \\
\text { Palegawra } \\
\text { Cave }\end{array}$ \\
\hline $\begin{array}{c}\text { بروسهاو } \\
\text { Braidwood and ) } \\
\text { ( Howe, } 1960\end{array}$ & فرايارينهسنگَى متأخر، & $\begin{array}{c}\text { كاوش } \\
\text { Excavate } \\
1960\end{array}$ & $1300 \mathrm{~m}$ & $\begin{array}{c}\text { غرب زاكرس مركزى تنشت كرمانشاه } \\
\text { West-Central Zagros, } \\
\text { Tange Kensht - } \\
\text { Kermanshah } \\
\end{array}$ & $\begin{array}{c}\text { يناهگاهصخرهاى } \\
\text { ورواسى } \\
\text { Warwasi } \\
\text { Rockshelter }\end{array}$ \\
\hline $\begin{array}{l}\text { اسميت و يانگ } \\
\text { Young, and ) } \\
\text { (Smith, } 1966\end{array}$ & $\begin{array}{c}\text { فرايارينdسنگى متأخر، } \\
\text { ميانى؟ آغازين؟ } \\
\text { Late, Middle? } \\
\text { Early? } \\
\text { Epipaleolithic }\end{array}$ & $\begin{array}{c}\text { كاوش } \\
\text { Excavate } \\
1965\end{array}$ & $1420 \mathrm{~m}$ & 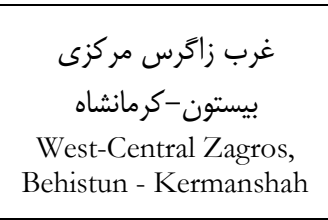 & $\begin{array}{c}\text { غار مَرخِريل } \\
\text { Mar Khrile } \\
\text { Cave }\end{array}$ \\
\hline 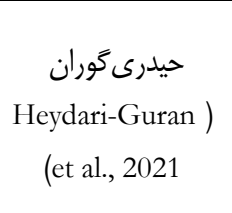 & $\begin{array}{c}\text { فرايارينdسنگى متأخر، } \\
\text { ميانى؟ } \\
\text { Late, Middle? } \\
\text { Epipaleolithic }\end{array}$ & $\begin{array}{c}\text { كاوش/بررسى } \\
\text { Excavate/Survey } \\
\text { 2016-18; } 2021\end{array}$ & $1300 \mathrm{~m}$ & 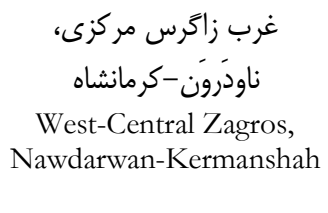 & $\begin{array}{l}\text { يناهگاهصخرهایى } \\
\text { Bawa Yawan } \\
\text { Rockshelter }\end{array}$ \\
\hline $\begin{array}{l}\text { هole ( هل و فلنرى } \\
\text { and Flannery, } \\
\text { (1967 }\end{array}$ & $\begin{array}{c}\text { فرايارينdسنگى متأخر؛ } \\
\text { ميانى آغازين؟ } \\
\text { Late, Middle? } \\
\text { Early? } \\
\text { Epipaleolithic }\end{array}$ & $\begin{array}{c}\text { كاوش } \\
\text { Excavate } \\
1965\end{array}$ & $1240 \mathrm{~m}$ & $\begin{array}{c}\text { غرب زاكرس مركزى، خرم } \\
\text { آباد } \\
\text { West-Central Zagros, } \\
\text { Khoramabad }\end{array}$ & $\begin{array}{c}\text { يناه گاهصخرهای } \\
\text { Pa Sangar } \\
\text { Rockshelter }\end{array}$ \\
\hline
\end{tabular}




\begin{tabular}{|c|c|c|c|c|c|}
\hline $\begin{array}{c}\text { مورتنسن؛ داودىى؛ دارابى } \\
\text { Mortensen, ) } \\
\text { 1993; Davoudi } \\
\text { and Abbasnejad } \\
\text { (Seresti, } 2016\end{array}$ & $\begin{array}{c}\text { فرايارينdسنگى ميانى؟ آغازين؟ } \\
\text { Late, Middle? } \\
\text { Early? } \\
\text { Epipaleolithic }\end{array}$ & $\begin{array}{c}\text { كاوش/بررسى } \\
\text { Excavate/Survey } \\
1974\end{array}$ & $1145 \mathrm{~m}$ & $\begin{array}{c}\text { غرب زاگرس مركزى، } \\
\text { هُليلان-ايلام } \\
\text { West-Central Zagros, } \\
\text { Holailanl-Ilam }\end{array}$ & $\begin{array}{c}\text { غار مَرَّرُ كَلان } \\
\text { Mar Gurgalan } \\
\text { Cave }\end{array}$ \\
\hline $\begin{array}{l}\text { مورتنسن؛ داودى } \\
\text { Mortensen, ) } \\
\text { 1993; Davoudi } \\
\text { and Abbasnejad } \\
\text { (Seresti, } 2016\end{array}$ & $\begin{array}{c}\text { فرايارينdسنكى متأخرى آغازين؟ } \\
\text { مينى } \\
\text { Late, Middle? } \\
\text { Early? } \\
\text { Epipaleolithic }\end{array}$ & $\begin{array}{c}\text { كاوش/بررسى } \\
\text { Excavate/Survey } \\
1974\end{array}$ & $1143 \mathrm{~m}$ & $\begin{array}{c}\text { غرب زاكُرس مركزى } \\
\text { هليلان-ايلام } \\
\text { West-Central Zagros, } \\
\text { Holailanl-Ilam }\end{array}$ & $\begin{array}{c}\text { غار مَرروز } \\
\text { Mar Ruz Cave }\end{array}$ \\
\hline
\end{tabular}

غذايى بلهنوان انتخاب شـيوهُ جديد معيشـتى توسـط

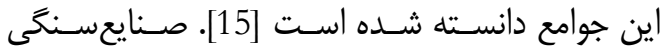

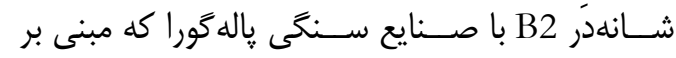

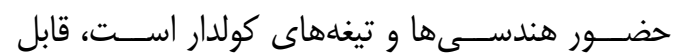
مقاي سه به نظر مىر سد. يك نمونه زغال سن سنجى

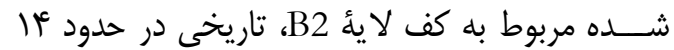

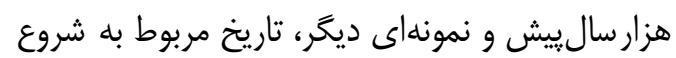

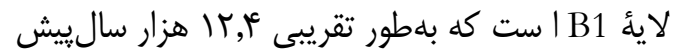
را نشانمىدهد. سولكى براساس مشاهدة تغييرات در

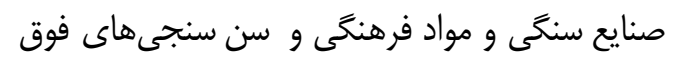

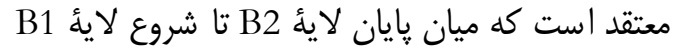
دو هزار ســـال وقفه وجود دارد [17]. غانيم وحيدا

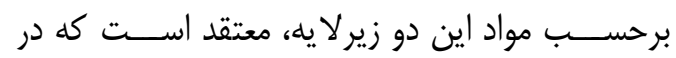
كونه شنا سى ابزارها و تداوم و تكامل محلى ابزارها از

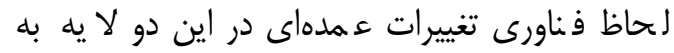
وجود نيامده اسـت. تنها تفاوت موجود در اين دو لايه، حضور فراوان سنگسابها و تزئينات شخصى در لائٔ

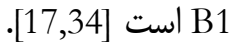

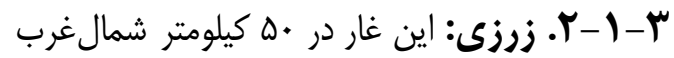

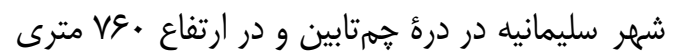

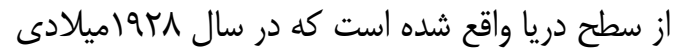

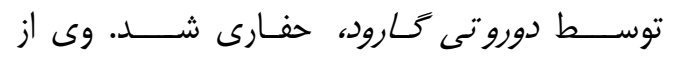

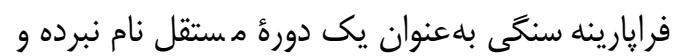

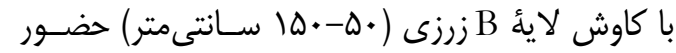

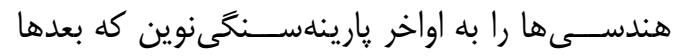
بهعنوان فرهنَ زرزى شناخته شد، منتسب مى كند.

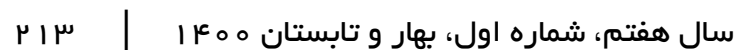

ا I-r. ز زاترس شمالى: زاترس شمالى كه بيشتر آن شـامل منطقع كردسـتان عراق اسـت، با طول تقريبى

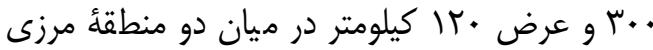

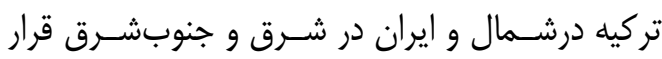
دارد. بيشتر مكانهاى يارينه سنكى شناس سايى شده از

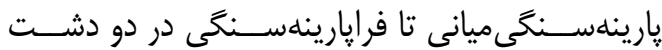

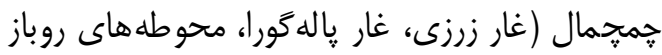

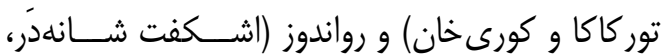
اشكفت براك، اشكفت حاجيه، اشكفت بابخال) توزيع

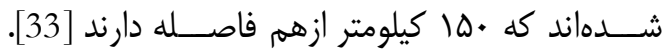
منطقة كردستان عراق درواقع در مركز هلال حاصلخ فاصلخيز

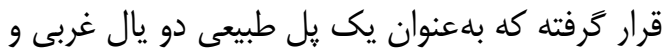

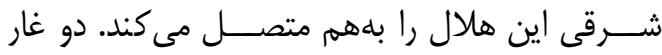

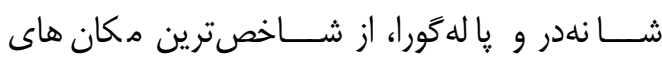

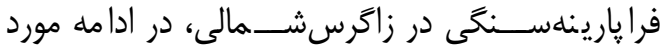
بررسى قرار مى گيرند.

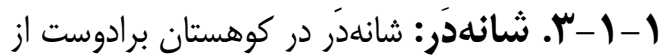
توابع استان اربيل در كردستان عراق واقع شده است،

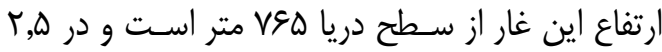

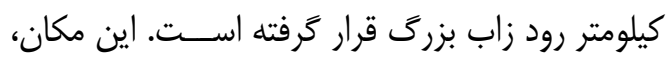

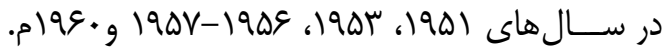
توسـط سـولكى مورد كاوش قرار كرفت. لائ B اين

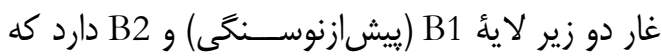
سولكى با مشاهدة تمركز هندسىها و تيغههاى كولدار

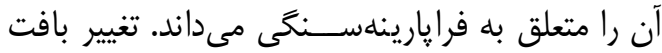
خاك، حضور فراوان يو سته صدف و خالههاى ذخيره 


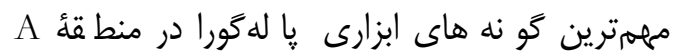

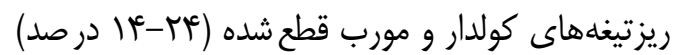

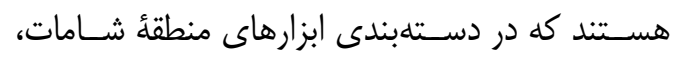

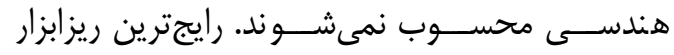

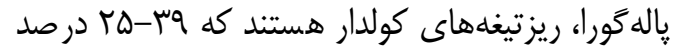

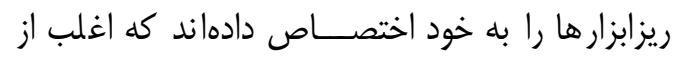

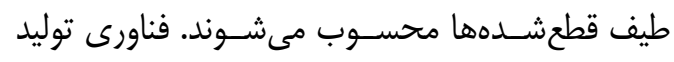

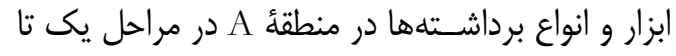
ســه، حاكى از اين اســت كه تغييرات كمى در طول

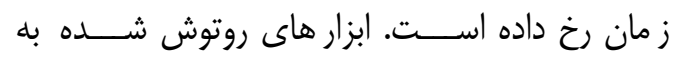

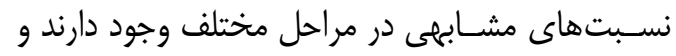

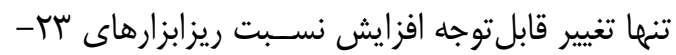

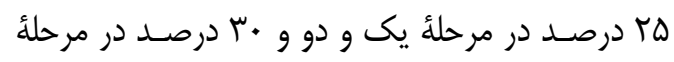

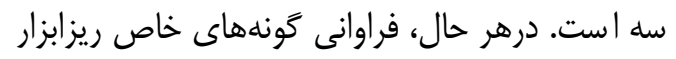

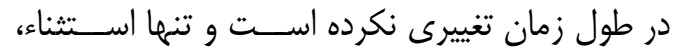

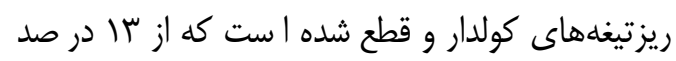

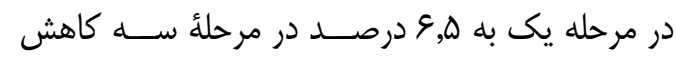

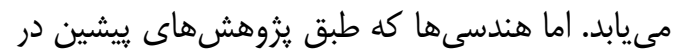

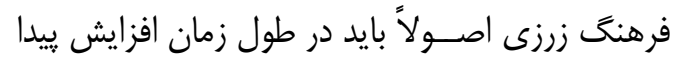

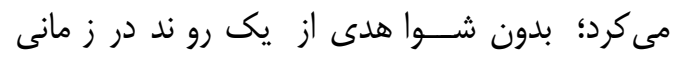

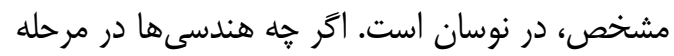
ســه نسـبت به مرحلة يكى بيشتر هســتند، بالاترين

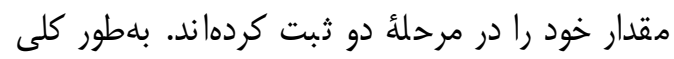

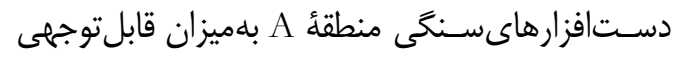

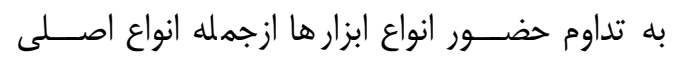

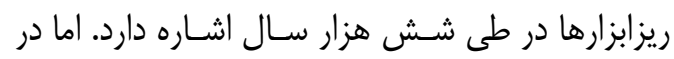

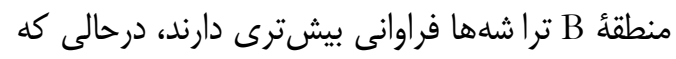

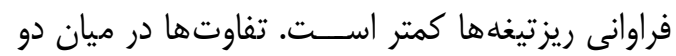
منطقه امكان دارد به كاربرى متفاوت محله دها اشــاره

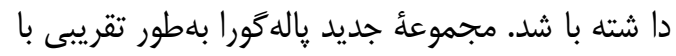

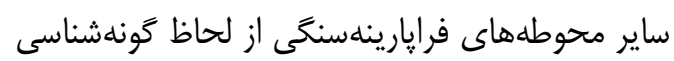
و فناورى مشابه است [17].

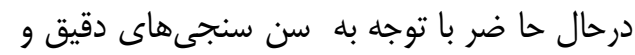

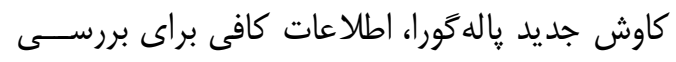

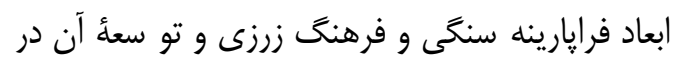

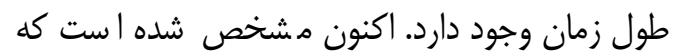

كارود، اين صــنعت را براســاس آنجه وى بهعنوان

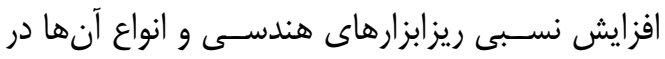
طى زمان مشــاهده كرده بود، به دو فاز اوايل و اواخر

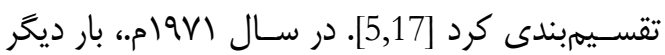
لايئ B غار زرزى توسـط وحيدا كاوش شــــ [35]. به

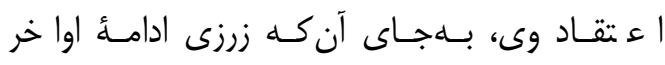
يارينه سنگى نوين معرفى شود، بهتر است يكى صنعت

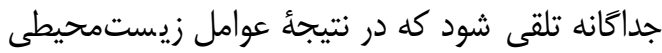
و كاركرد د ستافزارهاى خاص اين دوره شكل كرفته دئه

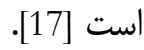

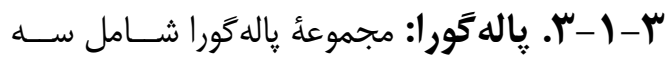

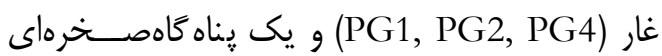
بوده كه در دامنههاى شمال غربزاگرس و در

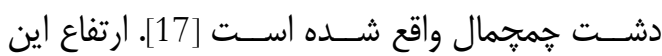

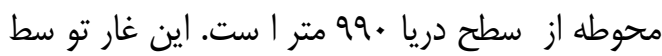

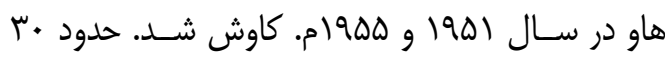

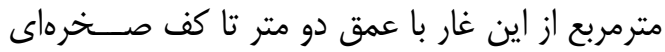

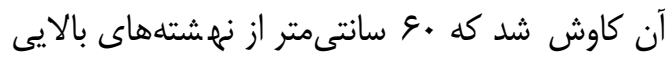

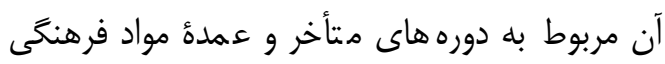

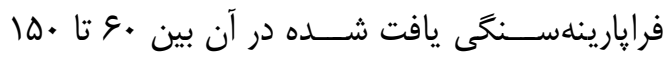

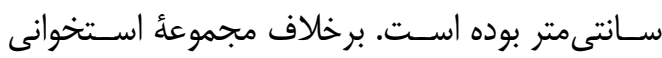

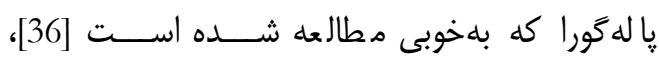

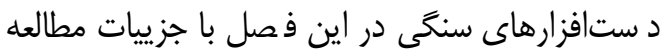

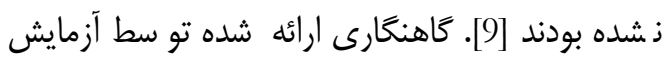

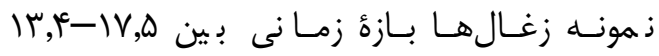

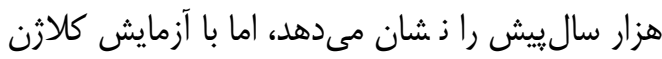

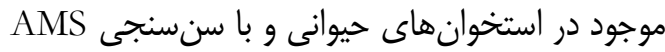

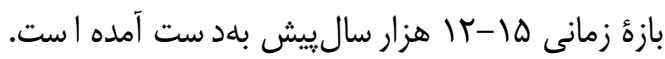

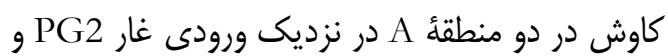

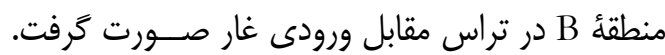

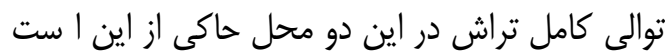

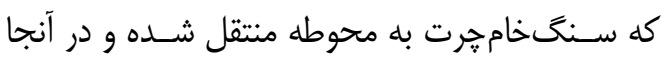

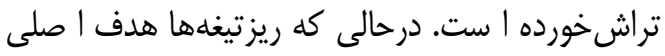

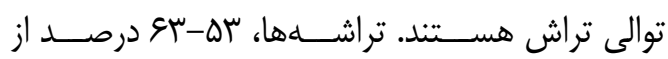
برداشتهها را به خود اختصاص دادهاند [17]. 
استان هاى كرمانشاه و خرمآباد است، تعداد مكانهاى

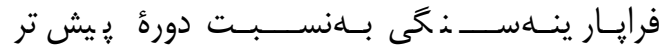

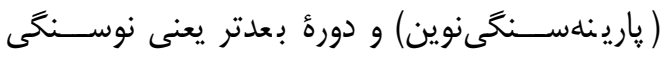

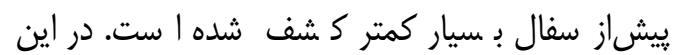

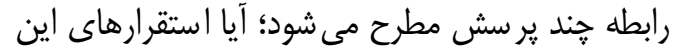

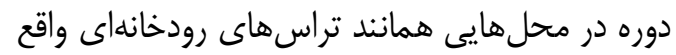

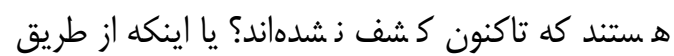

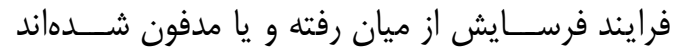

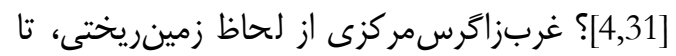

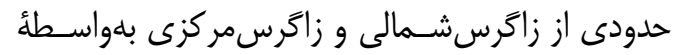

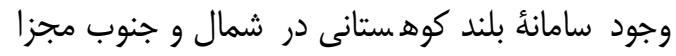
مىشود. اين منطقه ازلحاظ فراوانى دشتهاى وسيع و

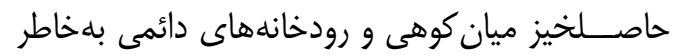
ويزگى هاى زمين شنا سى بـسيار غنى است. براس ساس كزارش هاى باستان شناسى در مكان هاى منطقه مورد

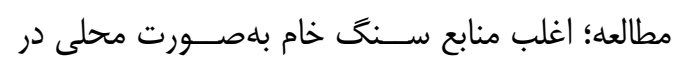

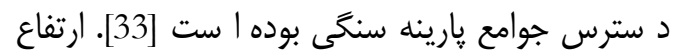

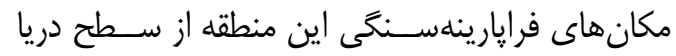

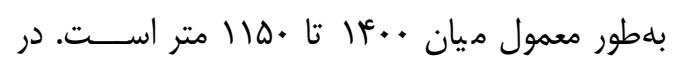

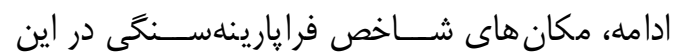
منطقه مورد بررسى قرار مى گيرد.

ו-r-r. ورواسى: يناهگاهصخرهاى ورواسى در 19 كيلومتر شمالشرق كرمانشاه در تنگ كنشت واقع شده اسـت كه در سـال • •19 ميلادى توسـط هاو كاوش

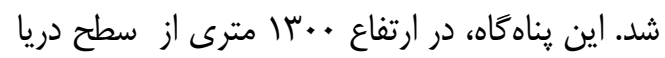

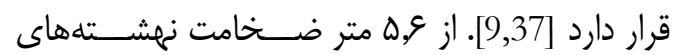

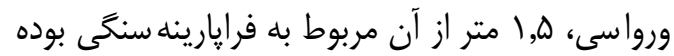

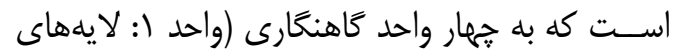

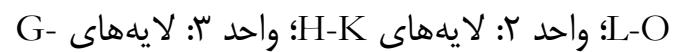

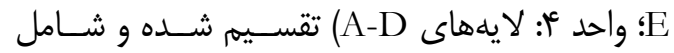

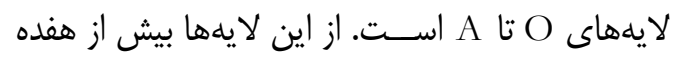

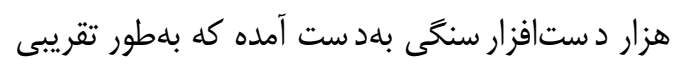
هـ\% درصد از دستافزارهاى هر واحد شامل ريزابزارها

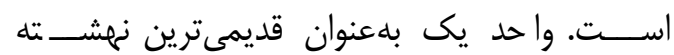

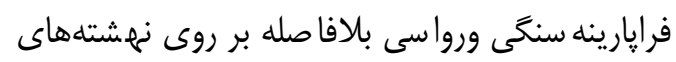

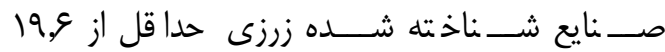
هزارسالييش (بلهورتقريبى از آخرين بيشينأيخحالى)

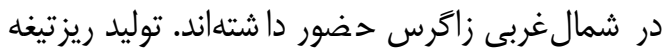
هدف نهمايى فناورى بوده كه اين هدف با حضـــور

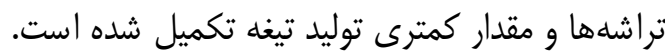

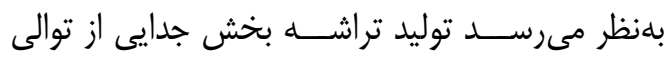
كـاهش و همجينين نمـايسان

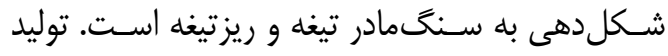

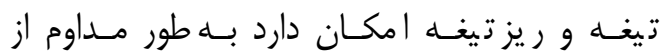

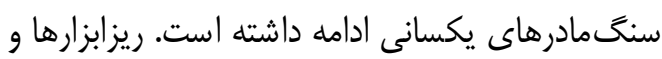
ريزتيغهها و تيغههاى دندانهدار ازجمله د ستلهبندى إنهاى اصلى گونه ابزارى هـستند كه با حضور هرجند كم اما

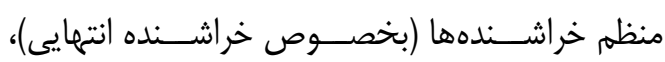

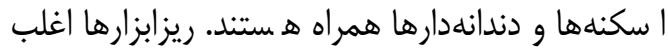

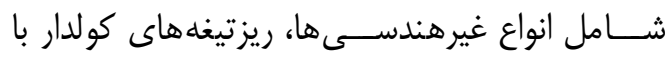

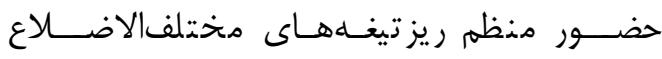
(بهاحتمالزياد، بسـيارى از آنها با فناورى ريزاسـكنه

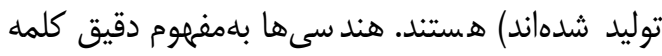

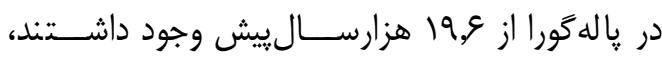

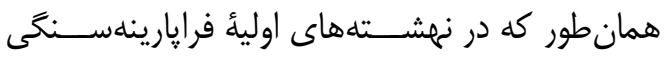

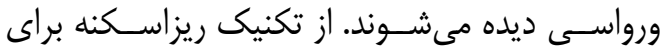

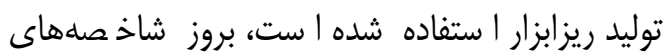

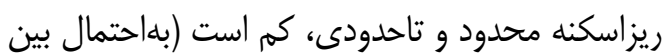

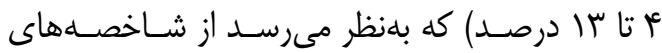

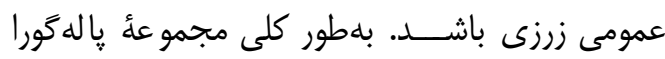

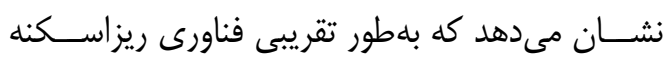

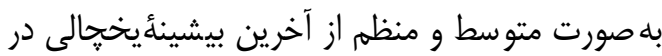

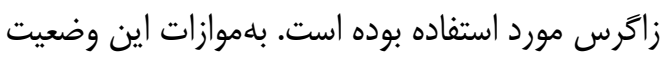

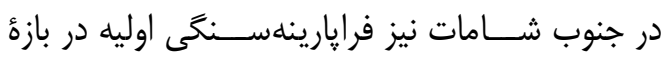

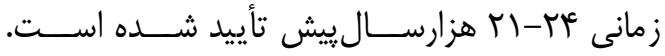
شاخصههاى ريزاسكنه نشان دهندة اين است كه تضاد

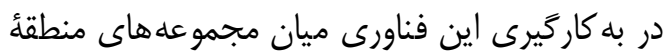
شامات و فرهنگ زرزى ديده مى شود [17]. r-r. غربزاترسمركزى: براســـاس مدارى باسـتانشــاسـى در غربزاترسمركزى كه شـامل 
علاوهبر حضــور نســبى هلالىهـا و ريزابزارهـاى

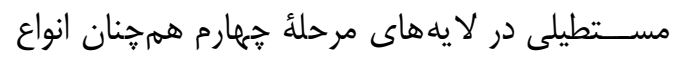

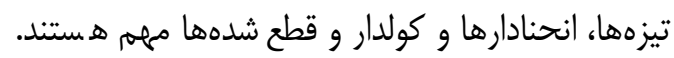

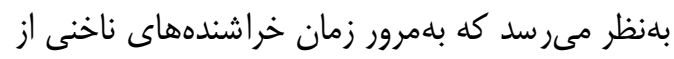
اهميت كمترى برخوردار شــــداند. عالاوهبر اين، تعداد

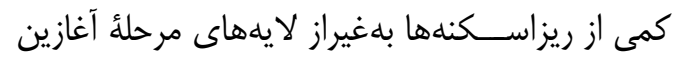

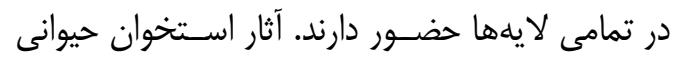

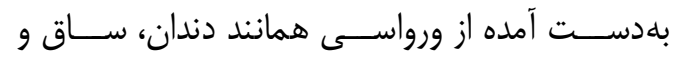

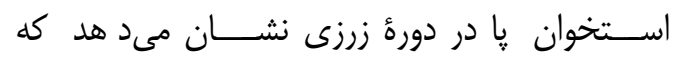

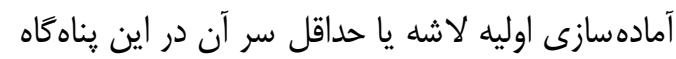

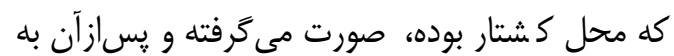
مكانهاى ديخر انتقال يافته است [10].

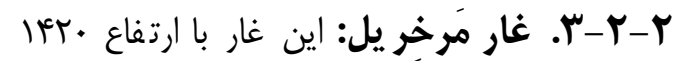

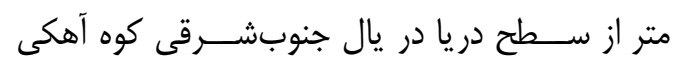

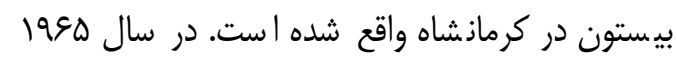

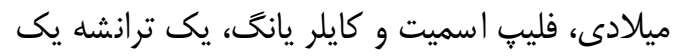

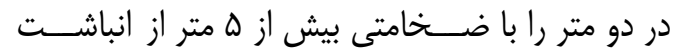

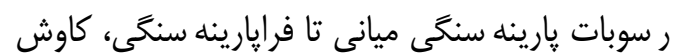

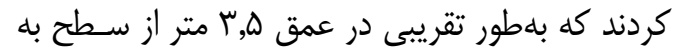

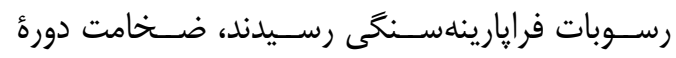
فرايارينه سنكى آن شامل يك متر است [11]. از لحاظ

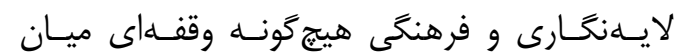

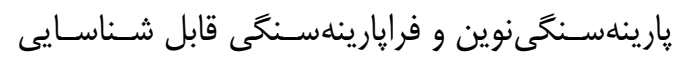

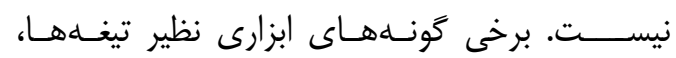

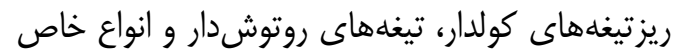

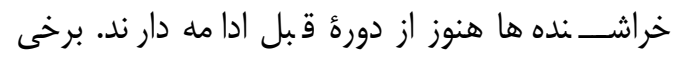

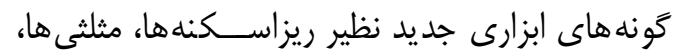

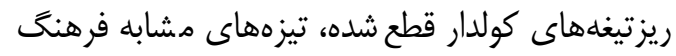

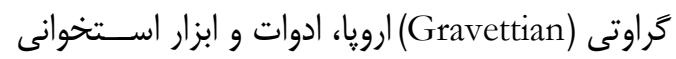

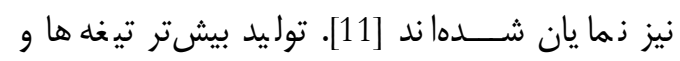

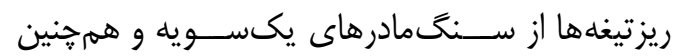
كمبود قطعات زورقى شكل عمدهترين تغييرات فناورى

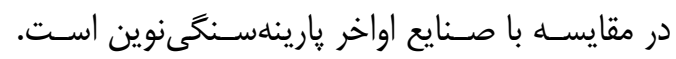

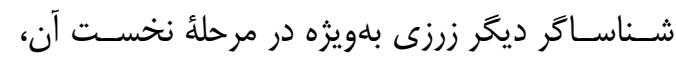

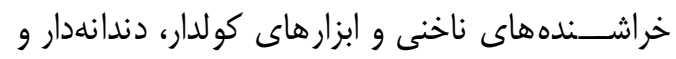

يارينهسنگىنوين قرار گرفته است. بلهورى كه صنعت

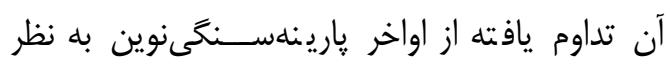

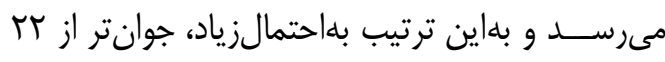

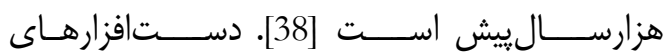

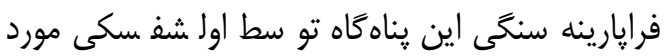

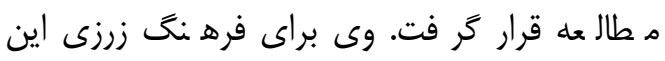

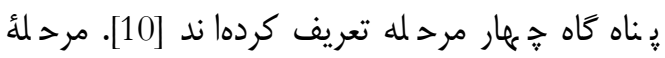
آغازين (لايههاى L-O آناه

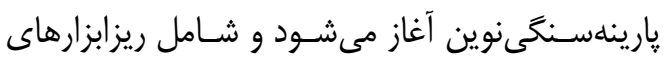
غيرهندسـى، ريزتيغههاى دوفور، دندانهدار و كنخر هدار

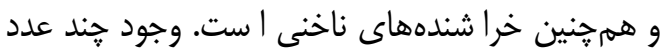

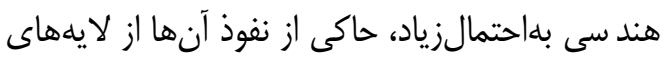

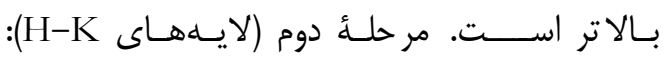

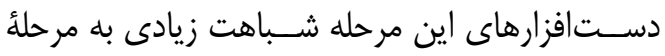

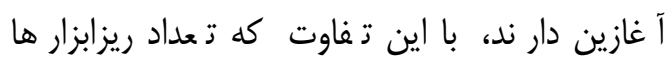

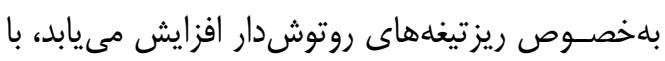

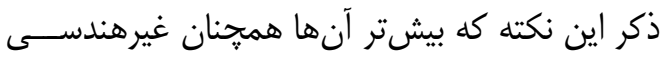

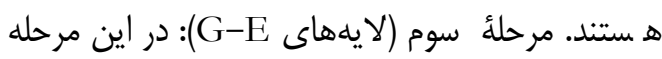

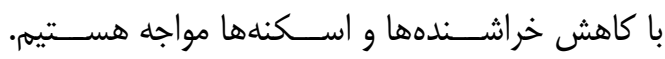

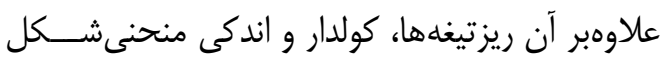

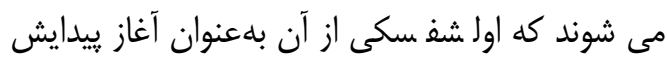

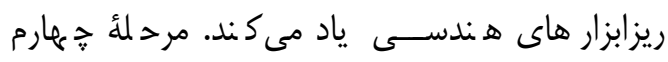

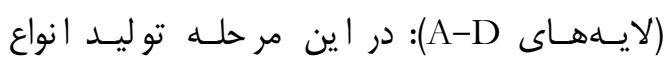
ريزابزارهاى هند سى افزايش و غيرهند سى إها كاهش

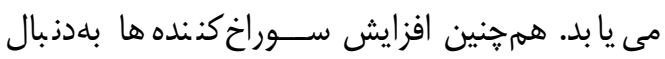

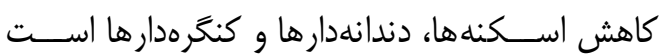
[10,39]. برخلاف تمايز مرحلئ آغازين با مراحل ديخر كه بلهور كل غيرهند سى هستند، مرحلة دوم و سوم

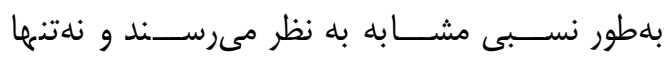

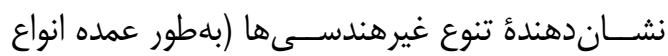

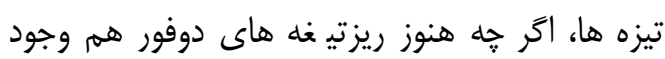

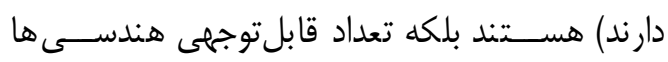
(باطور عمده مختلف|لا ضلاع) را نيز شامل مى شوند. تفاوتى كه در ميان اين دو واحد ديده مى شود، افزايش

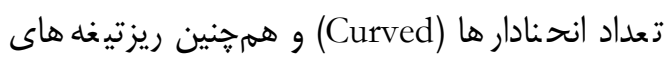

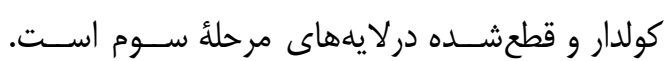


اين ابزارهاى سبك به بإيين دست باشد [14,41]. وى

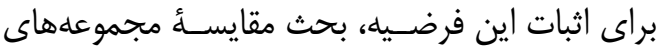

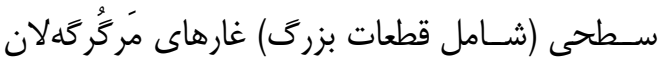

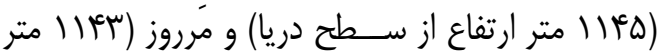

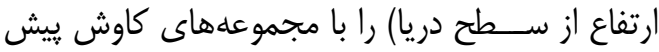

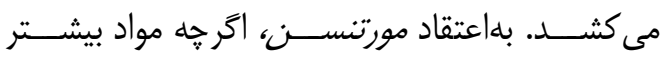
محوطههاى فرايارينه سنگى در هليلان بـسيار محدود اســت تا بتوان با قطعيت آنها را به اوايل و يا اواخر

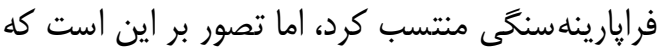

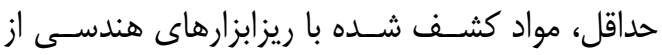

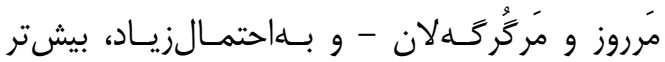
مجموعههاى ديخر - متعلق به مرحلة پايانى فرهنَ

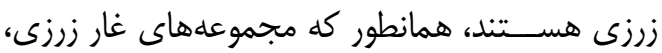

غار مرخريل و ورواسى اين را نشان دادهاند [14].

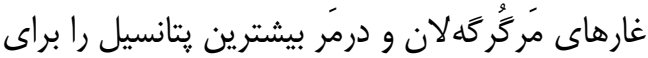

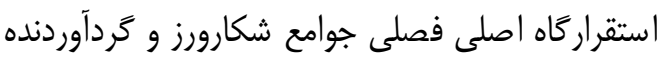

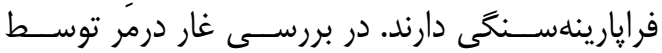

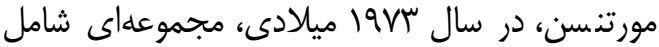

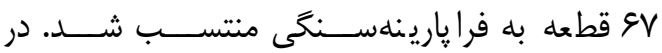

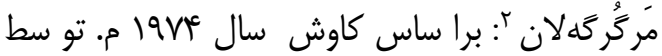
مورتنسن؛ نشان داده شد كه لايههاى B و C اين غار

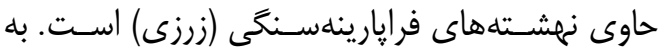

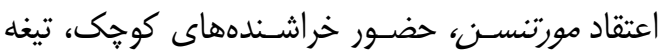

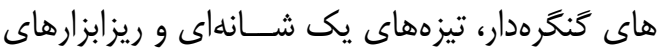

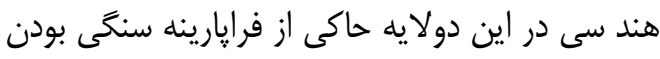

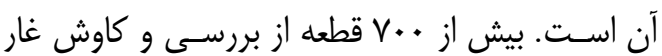

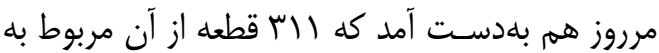

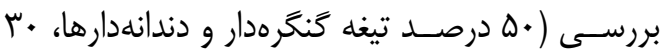

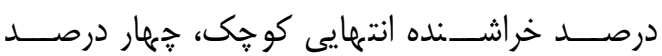
ريزتيغههاى كولدار، جهار در صد اسكنه و همرجنين دو دو

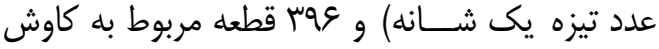

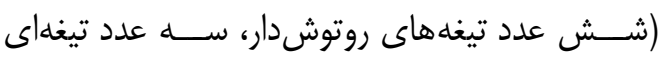

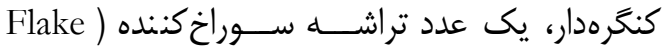
borer

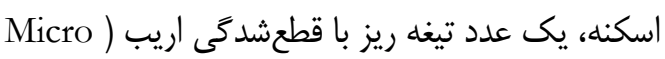
(blade with an oblique truncation
كنخرمدار بر روى ريزتيغه اســت. از ميان •ما قطعهُ مربوط بالين فاز و از بين معدود هندسـىهاى موجودي،

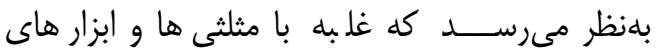
ذوزنقهاى شكل نامنظم باشد [40].

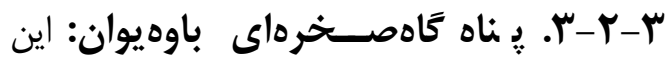
محوطه در منطقة ناودرون شهر ستان مركزى ا ستان

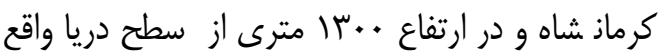

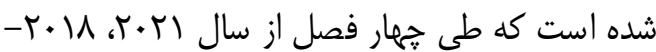

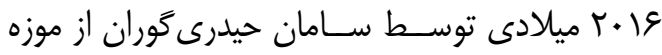
نئاندرتال آلمان كاوش شد. محوطه، داراى توالى سه سه

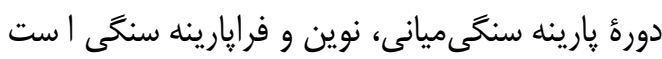

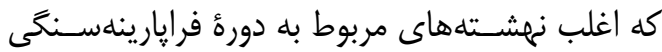

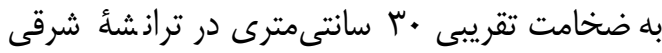

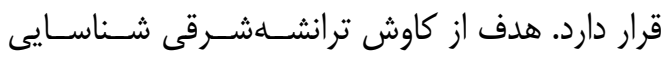

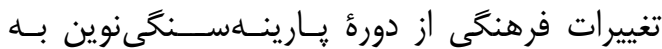

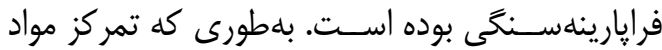

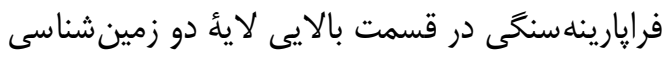

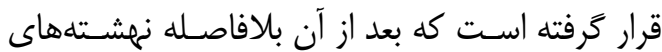

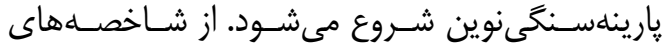

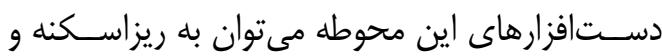

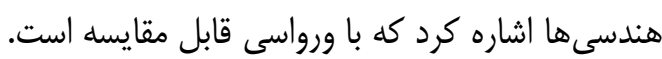

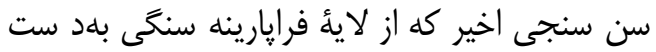

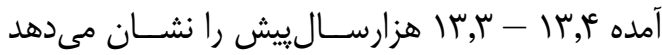

ع-ץ-ץ. دشت هليلان: اين دشت در شمال شرق استان ايلام واقع شده است. در بررسى سال 19V9 م.

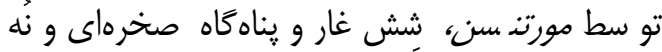

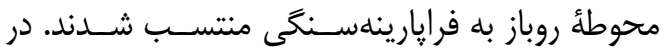
بيشتر محوطهها حضور خراشنده ناخنى مشهود است. از ديدگاه مورتنسن، تشخيص اواخر هارينه سنكى نونين

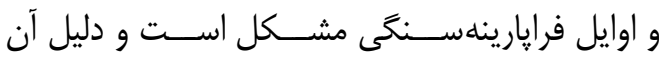
مى تواند نبود ابزار هاى هندسـى و و تيغه هاى ريز در

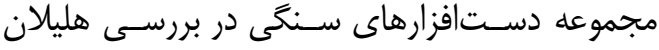
باشــ كه خود مىتواند بهدليل از ميان رفتن و غلتيدن 
يارينهسنگ نوين را در اين محوطه، زير سئوال مىبرد. همانند ورواسـى شــواهد بيشــترى از تداوم دو واحد

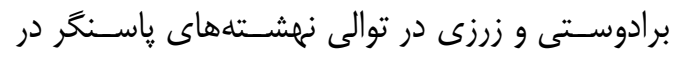

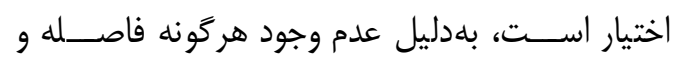

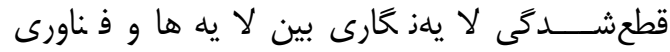

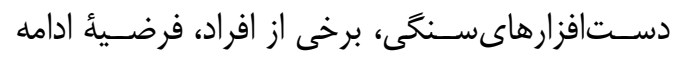

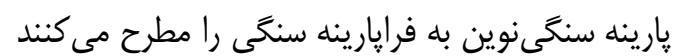

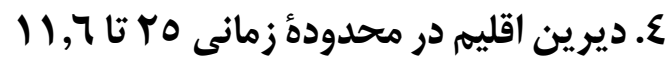

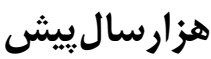

تداوم و تطور فرهنگى در كوهستان زاگرس، بـسيارى

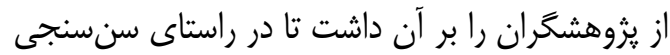
و بازسازى شرايط محيطى كذشته كامهايى بردارند. از سـال •19 م. م. تا به امروز يزوهش هايى در جهرت

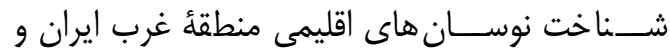

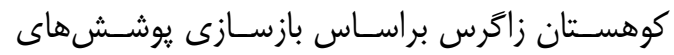

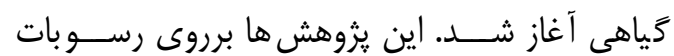

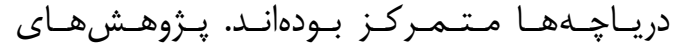

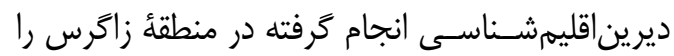

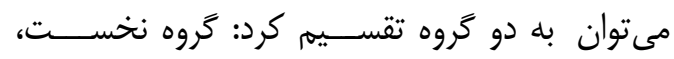

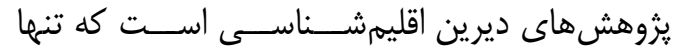

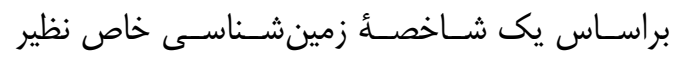

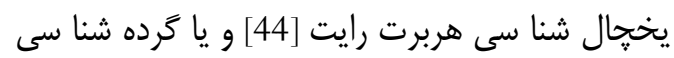

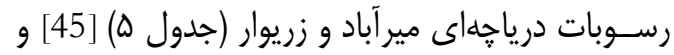

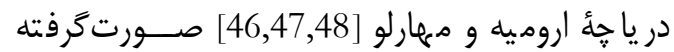

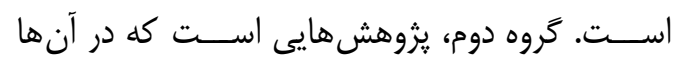

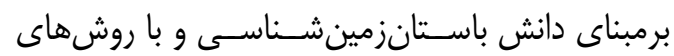
مختلف، دست به باز سازىهاى اقليمى زدهاند. ازجمله

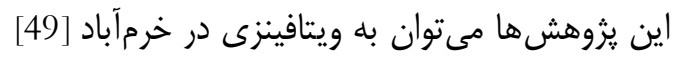

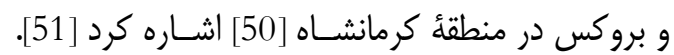
در سـالهاى اخير تالاب هشـيلان مغزهبردارى شــده

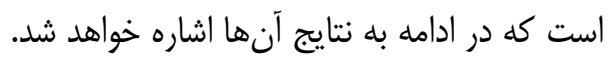

ريز كولدار و TVQ قطعه هم شامل بردا شتههايى نظير تراشه، تيغه و ريزتراشه) بوده است [11].

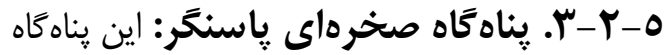

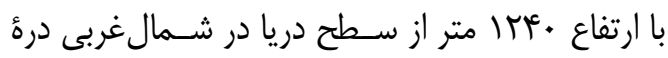

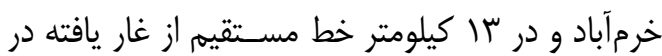
كوهيايههاى كوه سفيد واقع شده است. هول و فلنرىى

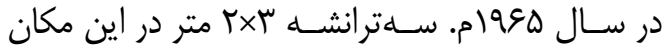

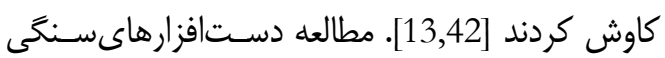
حـاكى از اســتقرار موقـت دو دوره يِيـايى اواخر

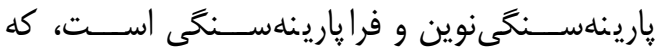

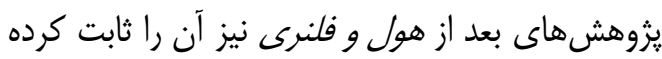

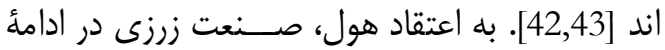
صـنعت برادوســى بارور شـــه اسـت و اين دو، دنباله

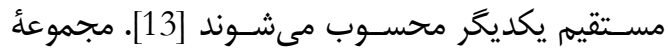

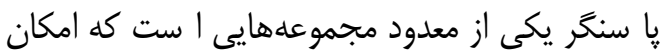

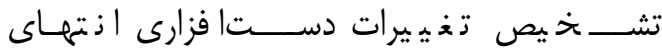

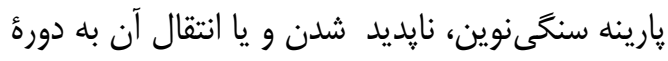

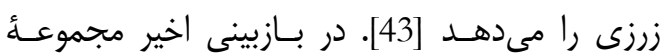

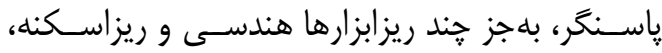

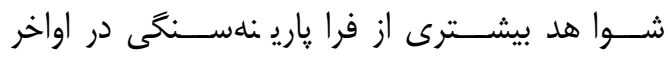
يارينه سنكى نوين بلدد ست نيامد و بنابراين وجود دورئ

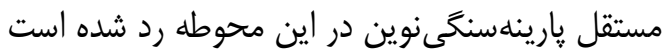

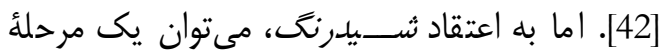

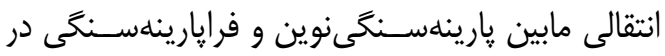
ֶا سنگ درنظر گرفت [43]. در پايان برادو ستى، توليد

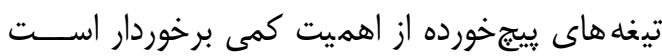

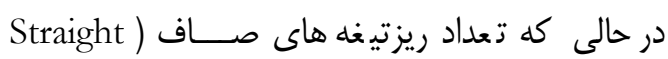

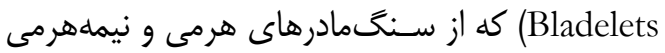
توليد مى شدند، جشم گيرتر است.

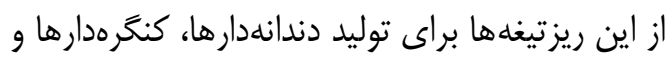
قطعات كولدار استفاده شده است كه در دوره برادوستى آنى

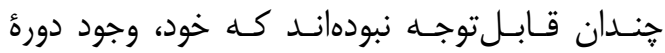


جدول ه: همكامسازى دادهاى درياجه زريوار با لايهنگارى زمانى مغزه يخى گر ينلند بروزه INTIMAT [17].

Table 5: Correlation of the lake Zeribar proxy data with the INTIMATE project Greenland ice core chronostratigraphy

\begin{tabular}{|c|c|c|c|c|}
\hline & 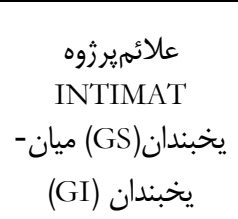 & 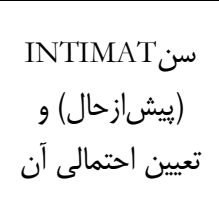 & 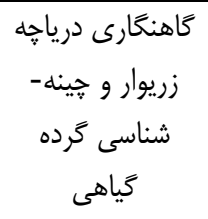 & طازسازى سير تطورى اقليم و يوشش كياهى از \\
\hline 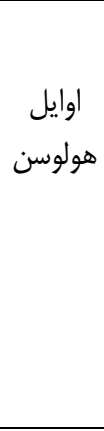 & $\begin{array}{l}\text { 8.2k BP event } \\
9.3 \mathrm{k} \mathrm{BP} \text { event } \\
11.4 \mathrm{k} \text { BP event }\end{array}$ & $\begin{array}{c}8300+10 /-40 \text { to } \\
8140+50 /-10 \\
9350+10 /-20 \text { to } \\
9240+30 /-10 \\
11.520-11.400 \\
11.703 \pm 4\end{array}$ & 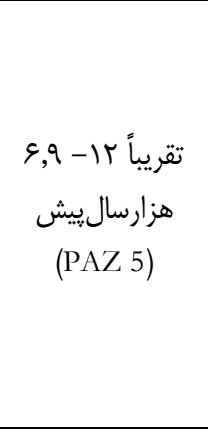 & 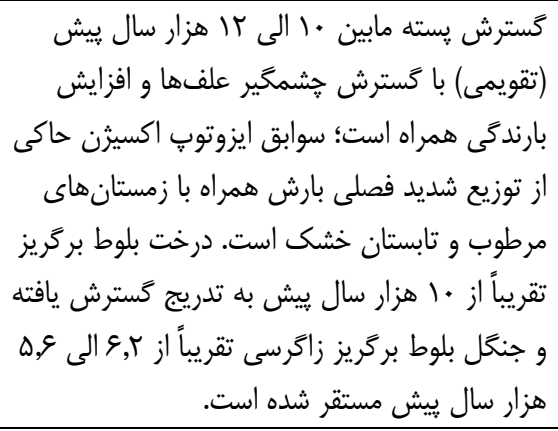 \\
\hline جرياس & GS-1 & $\begin{array}{l}12.896 \pm 4 \text { to } \\
\quad 11.700\end{array}$ & 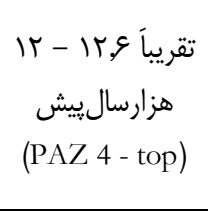 & 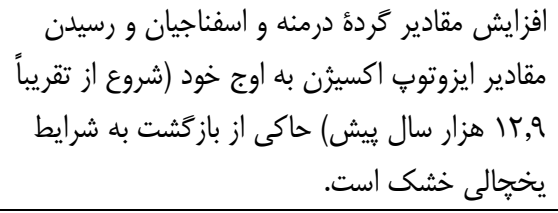 \\
\hline 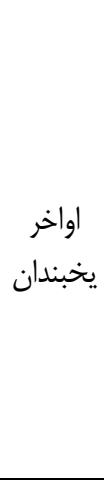 & $\begin{array}{l}\text { Gl-1 } \\
\text { Gl-1a warm } \\
\text { period } \\
\text { Gl-1b cold event } \\
\text { Gl-1c1 warm } \\
\text { period } \\
\text { Gl-1c2 cold event } \\
\text { Gl-1c3 warm } \\
\text { period } \\
\text { Gl-1d cold event } \\
\text { Gl-1e warm } \\
\text { period }\end{array}$ & $\begin{array}{l}14.692 \pm \text { to } \\
\quad \sim 12.900 \\
\text { Start at } 13.099 \\
\text { Start at } 13.311 \\
\text { Start at } 13.600 \\
\text { Start at } 13.660 \\
\text { Start at } 13.954 \\
\text { Start at } 14.075 \\
\text { Start at } 14.692\end{array}$ & 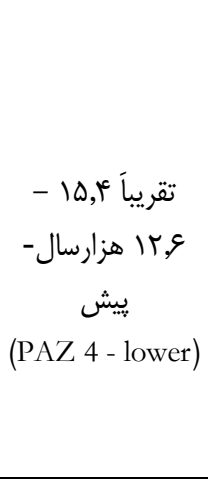 & 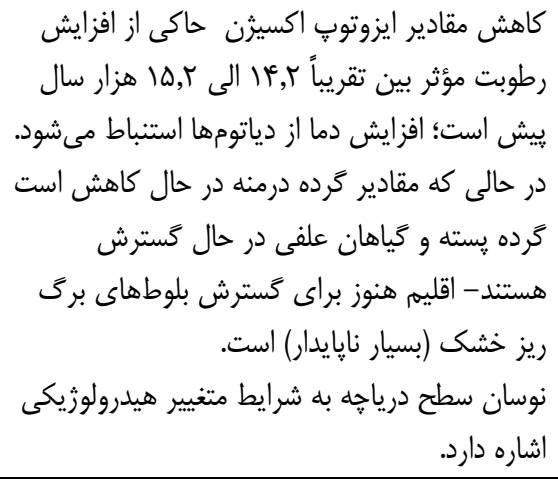 \\
\hline يخبندان & $\begin{array}{l}\text { GS-2.1 a } \\
\text { GS-2.1 b } \\
\text { GS-2.1 c }\end{array}$ & $\begin{array}{l}23.020-22.900 \\
23.220-23.020 \\
23.340-23.220 \\
27.540-23.340\end{array}$ & 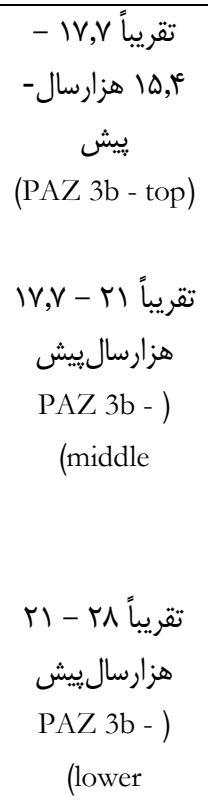 & 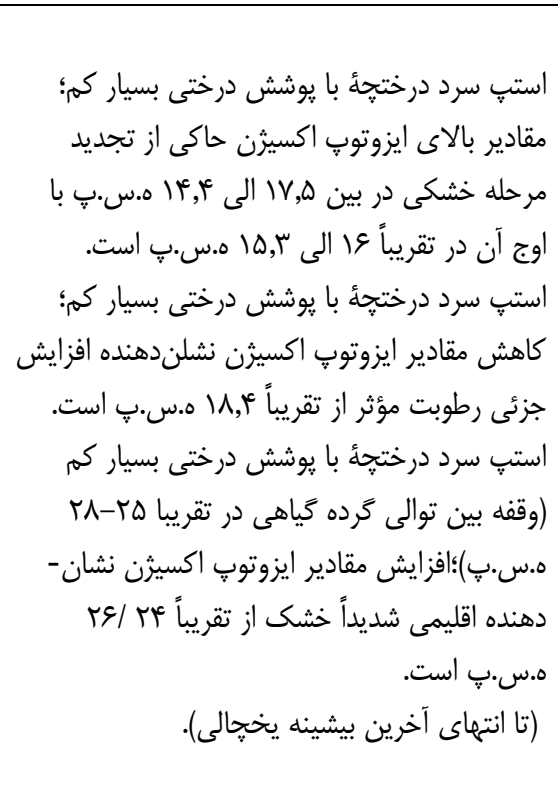 \\
\hline
\end{tabular}

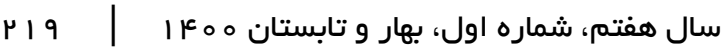


فراوانى درمهنه و گَندميان و كاهش اســفناجيان ع- (1. - هشيلان

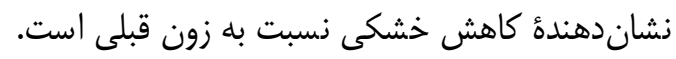

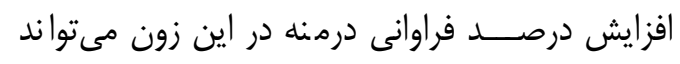
حاكى از افزايش بارش زمسـتانه باشــــ در اين زمان،

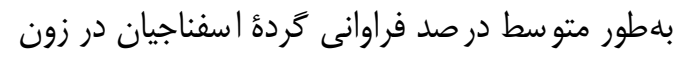

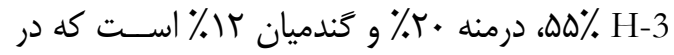
مقايسه با زون قبلى، درصد فراوانى اسفناجيان افزايش

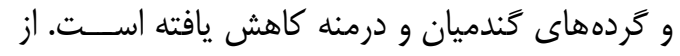

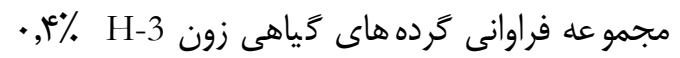

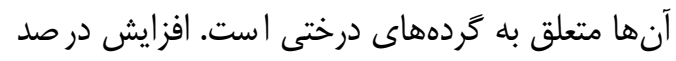

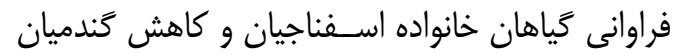

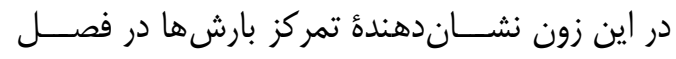

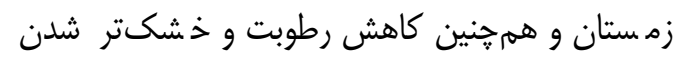

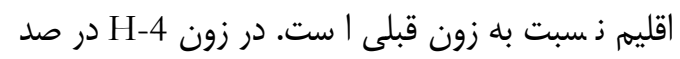

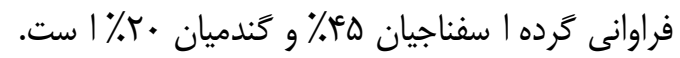

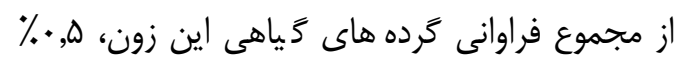

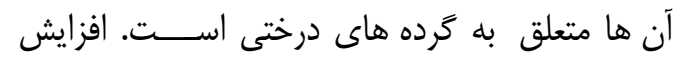

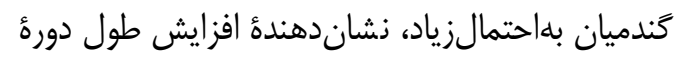
بارشى و وجود رطوبت در فصل گرم است كه بلهواسطئ

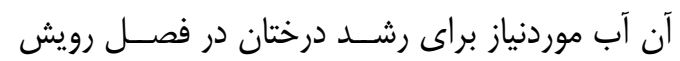

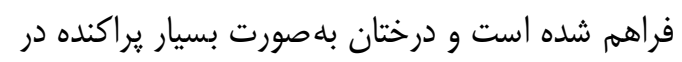

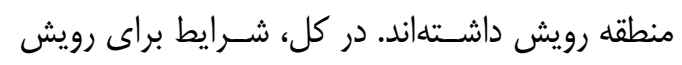

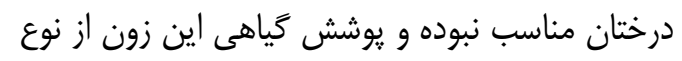

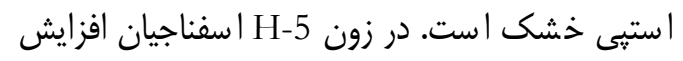

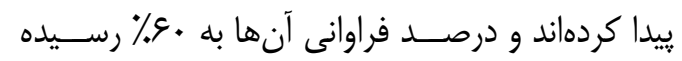

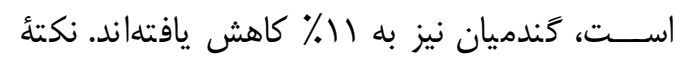
قابل توجه، درصـد فراوانى جنس هزارخار ( Cousinia-

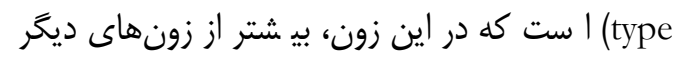

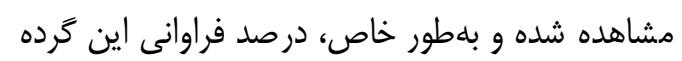

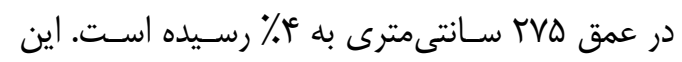

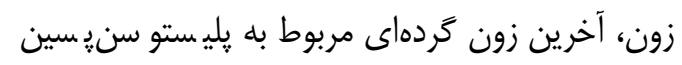

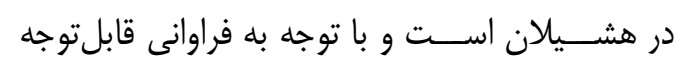

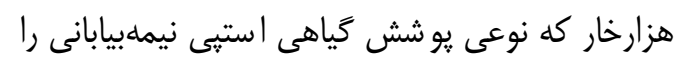

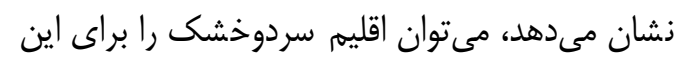

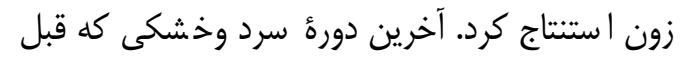

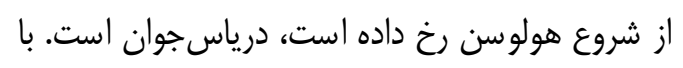

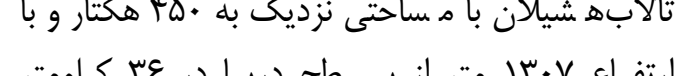

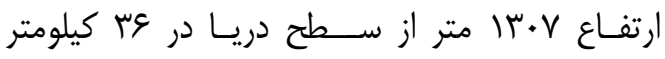
شمال غربى شهر كرمانشاه واقع شده است. در سال

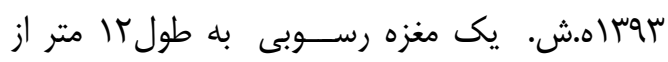

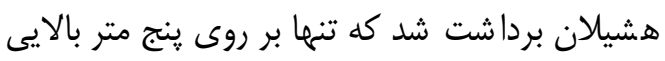

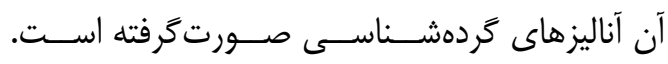

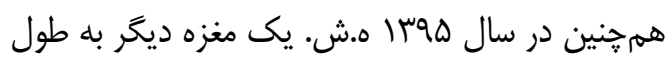

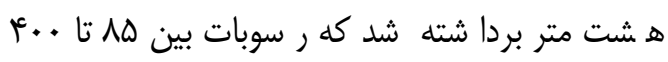

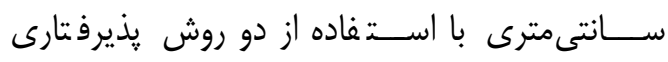
مغناطيسى (Magnetic susceptibility) و جِرِم كاهى كرمايشى بلعنوان روشهاى آنى و حساس براى ثبت

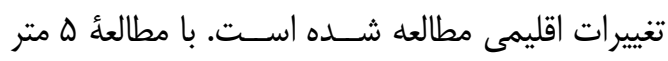

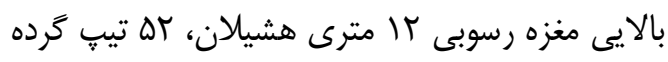

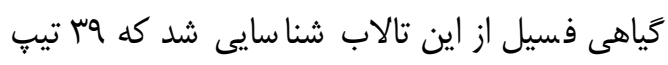

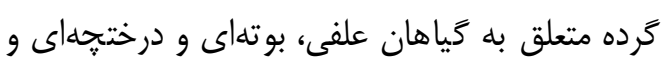

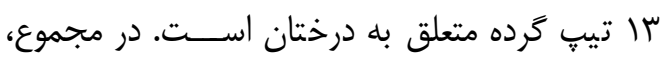

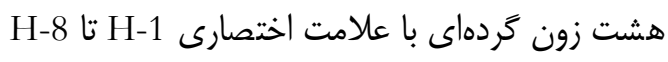

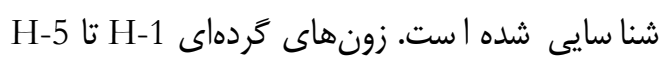

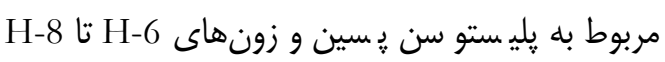

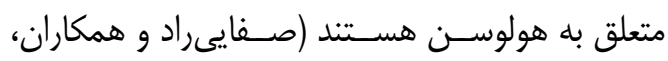

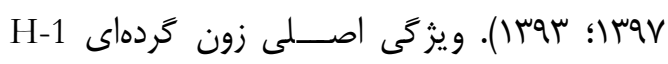

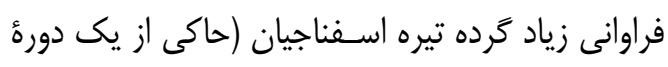

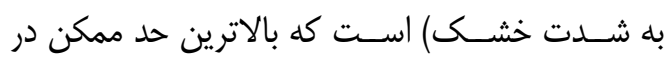

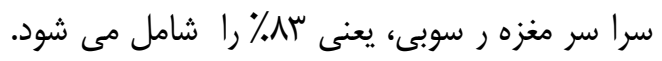

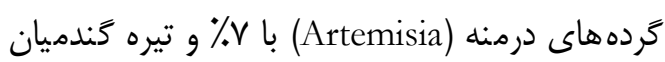

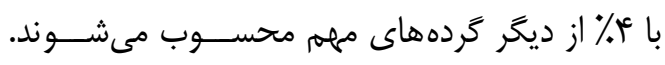

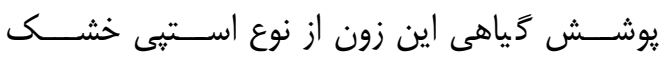

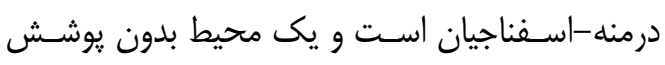

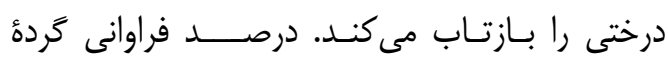

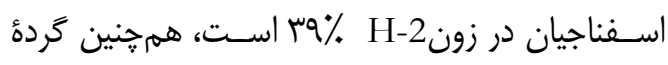

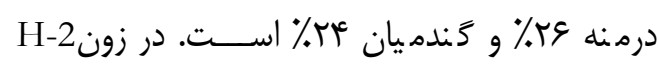

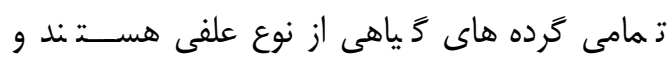

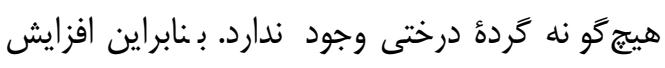

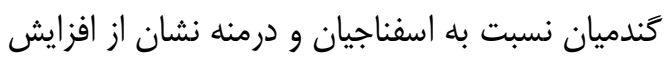

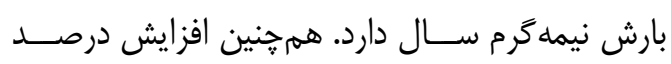


دادهاند، تا برر سى كنند كه جِكَنه جوامع در مواجهه با تغييرات محيطزيست دجار فرويا شى شدهاند و يا خود

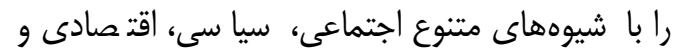

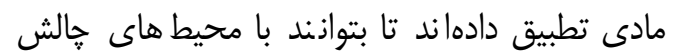
برانخيز شان سازكار شوند. يزوهشهاى مرتبط حاكى

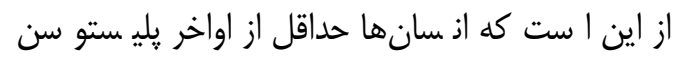

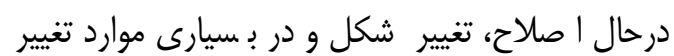

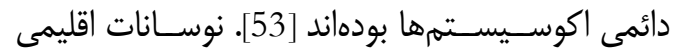

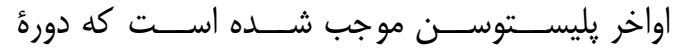

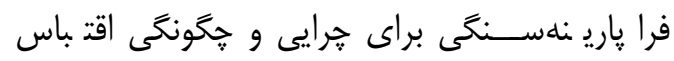
استراتزىهاى معيشتى در مقابله با اين نوسانات، مورد

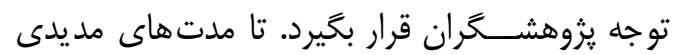

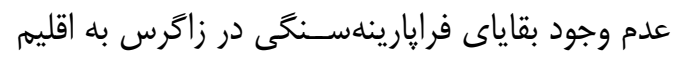

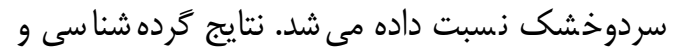

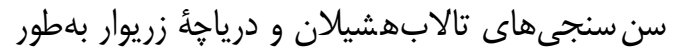
تقريبى نشــان داده اســت كه مراحل اقليمى كه در

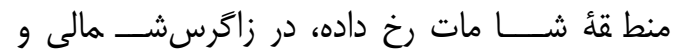

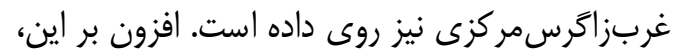

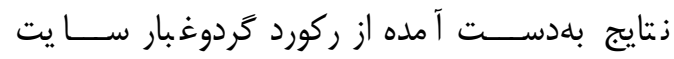
كنار صندل جيرفت واقع در منطقه جنوب شرقى ايران كه تغييرات آن با ركوردهاى ديرين اقليم جهانى و از

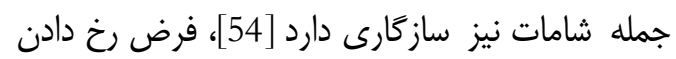

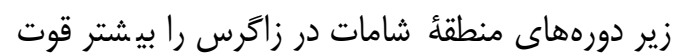

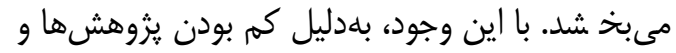

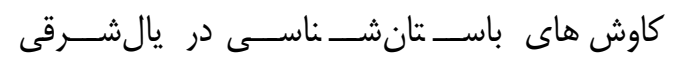

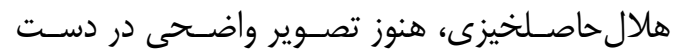

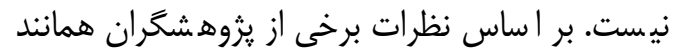

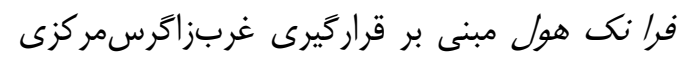

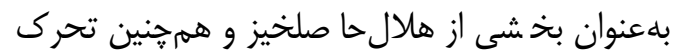
بسـيار بالاى جوامع شـكارورز و گردآورنده، نمى تهوان

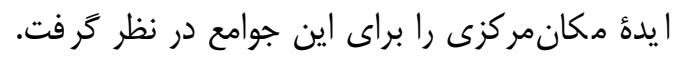

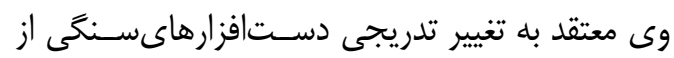

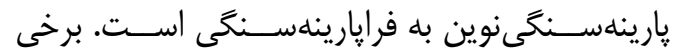
كو نه هاى ابزارى در مجمو عه هاى هر دو دوره ديده

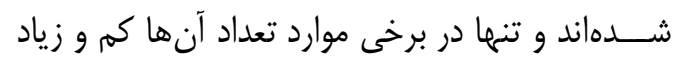

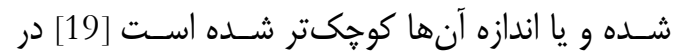

توجه به موارد فوق، مىتوان شــكل گيرى اين زون را در ارتباط با رخداد سردوخ شكى درياسجوان دان دان ست

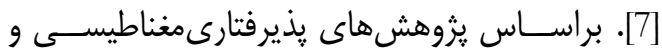

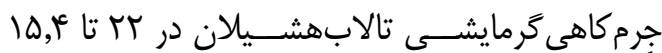
هزارســالييش رســوبات از نوع رســوبات درياجهاى

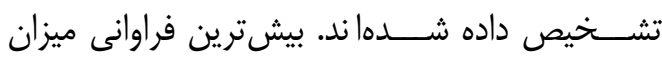

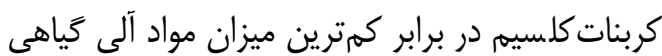

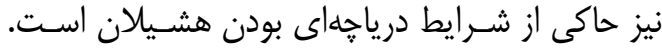

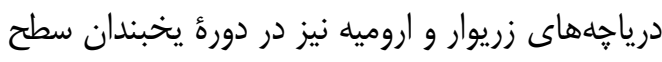

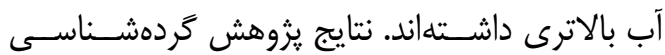
انجام شده بر رسوبات درياجه اروميه، درياجه زريوار و

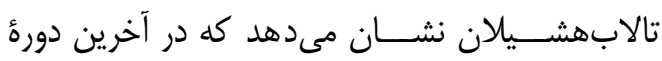

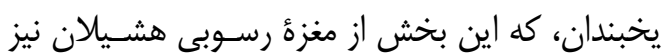

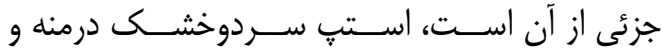

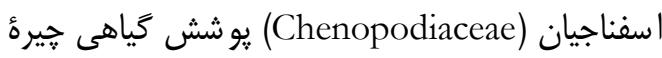
زاگرس بوده است. دليل اصلى درياجه بودن هشيانان و بالا بودن ســـح آب در يا خه هاى زاكرس در در اين شرايط اقليمى خشك و كم بار شى، كاهش خشمَّير

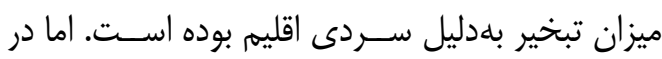

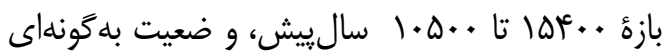

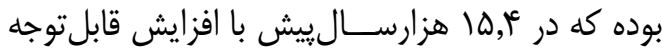
ميزان مواد آلى و كاهش شرد شديد كربنات كلا سيم مواجه هســتيه. نتايج آناليز داياتومهاى (Diatoms) درياجٍه

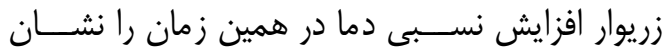

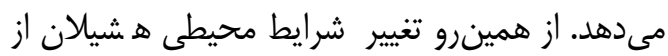

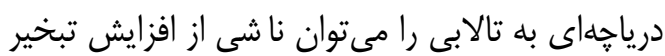

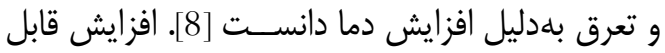

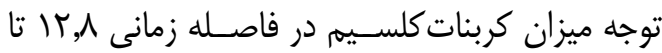

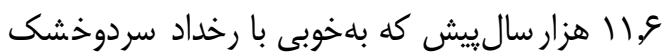
درياس جوان همزمان اســ، افزايش انحلال و ورود كربنات كلسيم را از آبخوان خورين به تالابهشيلان آنان

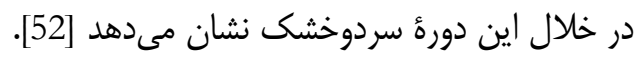

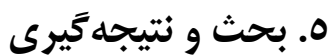

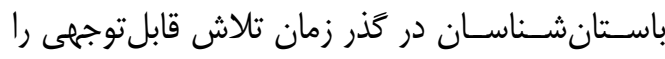

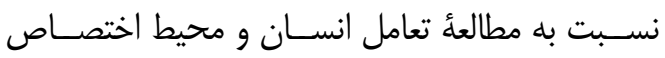


روال صدق نمى كند، بلكه شاهد حضور كمرنگ آنها

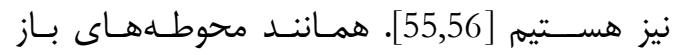

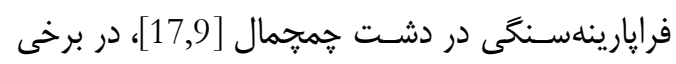
محوطههاى دره هوليلان [14] و محوطههاى لرستان،

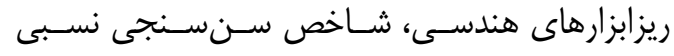

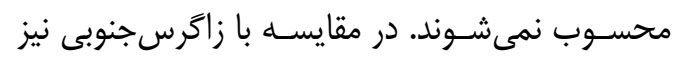

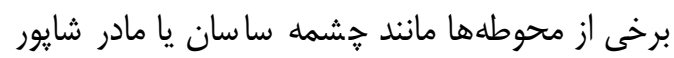

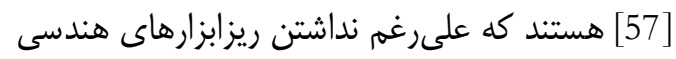

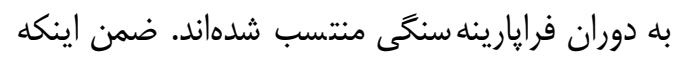

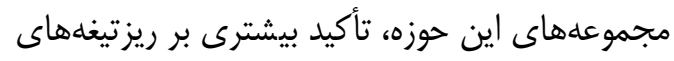

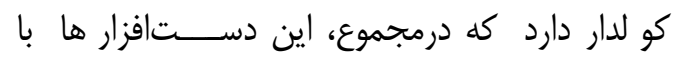
مجموعلهاى دشت ايذه شباهتهايى دارند [56]. نبود

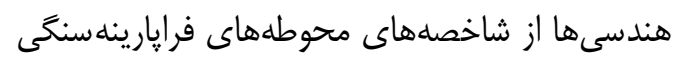

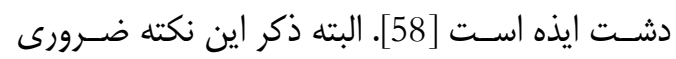

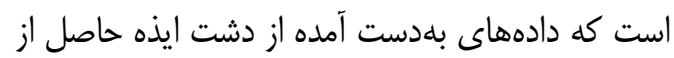

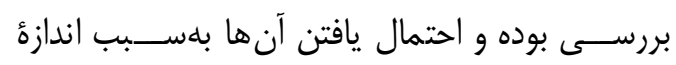

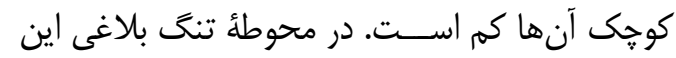

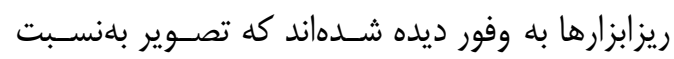

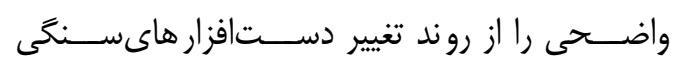

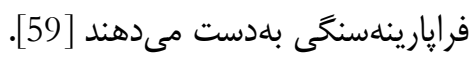
در غربزاخرسمركزى تغييرات ابزار در طول زمان

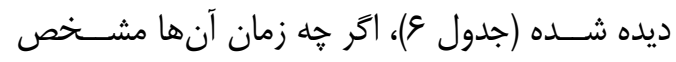

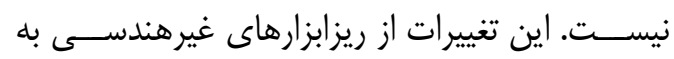

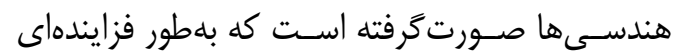

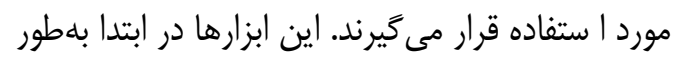

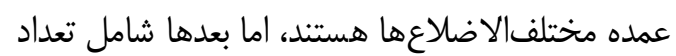
بيشترى از اشكال انحنادار از جمله هلالىها دما در اواخر

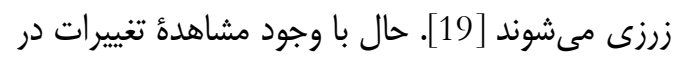
زمان دستافزارهاىسنگى ورواسى و با توجه به عقيدة اول شف سكى مبنى بر اينكه كه نمىتوان روند تغييرات

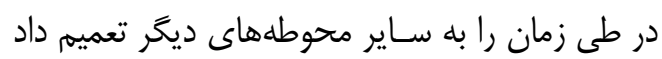

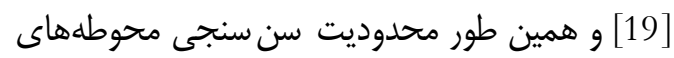

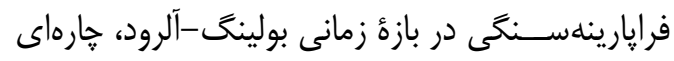

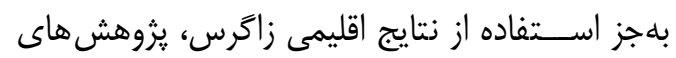

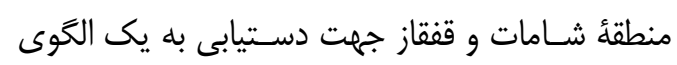
همحامسازى براى حداقل غربزاگرسمركزى ندارئ نداريه.
مقابل ســولكى معتقد اســت كه فرهنخ زرزى از

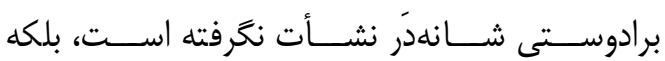

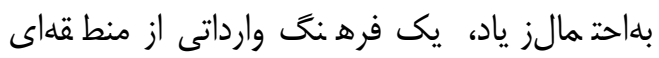

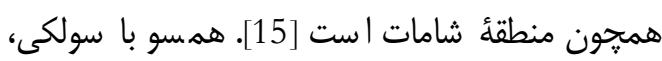

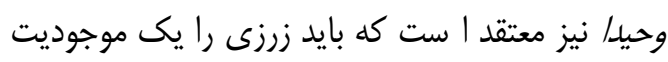

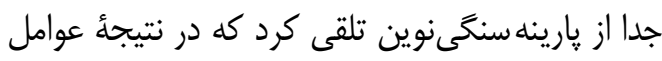

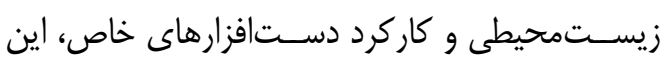

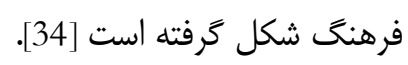

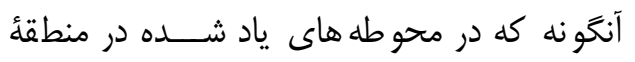

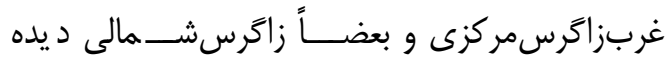

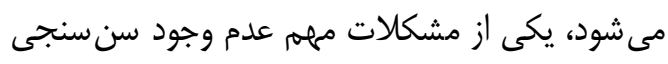

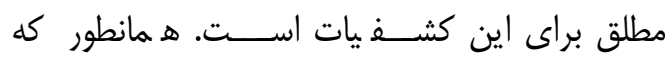

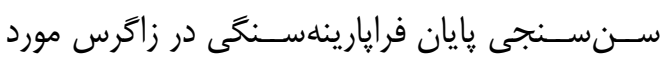

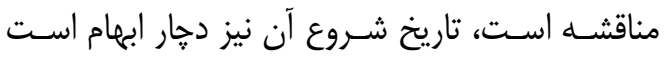

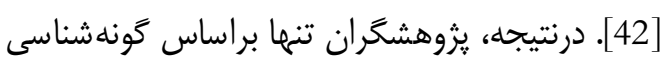

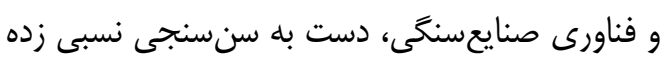

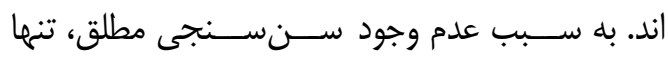

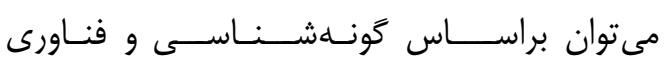

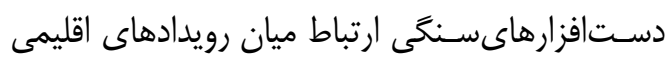

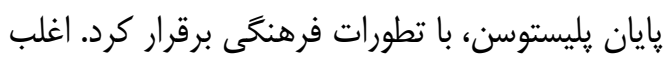

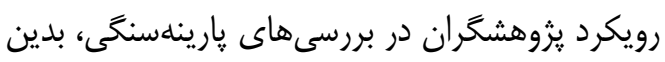

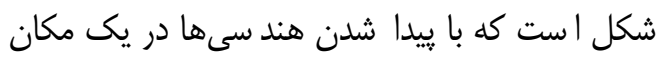

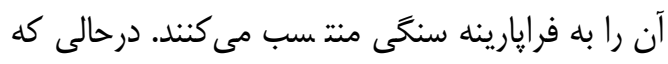

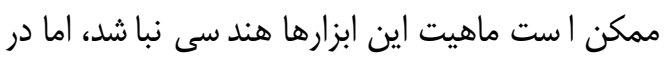

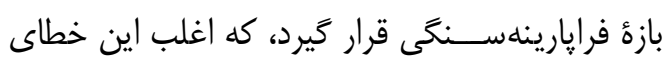
استراتزيك منجر به مستند شدن اين نوع ابزارها بلنام

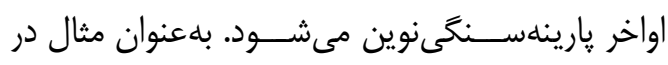
محو طه هاى روبازى جون تور كاكا و كورى خان كه

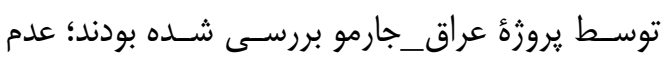

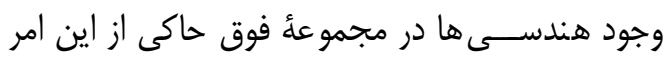

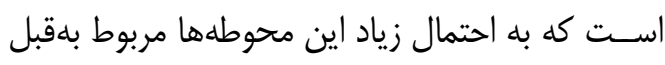
از محوطههاى زرزى و ياله گورا هستند [17]. به اعتقاد

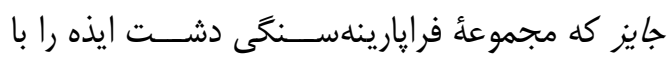

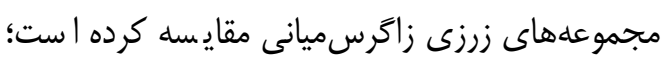

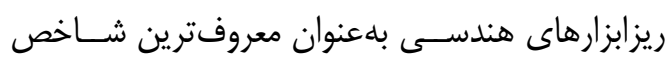
محوطههاى زرزى شـناخته شـدهاند؛ اما، هميشـهـ اين 
جدول : توزيع زمانى آزمايشى مكانهاى اصلى زرزى/فرايارينهسنگى [19].

Table 6: A Tentative Temporal Distribution of Major Zarzian Sites [19].

\begin{tabular}{|c|c|c|}
\hline Latest & 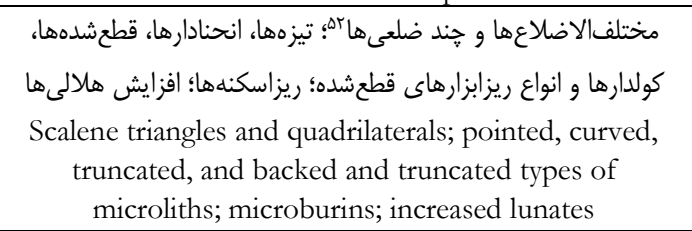 & 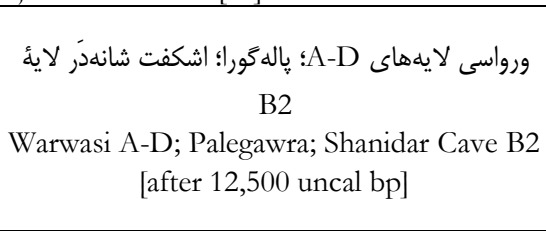 \\
\hline Later & $\begin{array}{c}\text { مختلف|لاضلاعها؛ انواع ريزابزارهاى انحنادار و تيزه؛ كمبود هلالىها؛ ريزاس اسكا. } \\
\text { Scalene triangles; pointed and curved types of } \\
\text { microliths; rare lunates; microburins }\end{array}$ & ورواسى لايههاى E-G؛ قسمت بالايى لايئ B غار زرزى \\
\hline Later & $\begin{array}{c}\text { مختلف|لاضلاعها؛ انواع ريزابزارهاى تيزهاى؛ ريزاسكنهها؛ خراشندههاى } \\
\text { Scalene triangles; pointed types of microliths; } \\
\text { microburins; thumbnail scrapers }\end{array}$ & 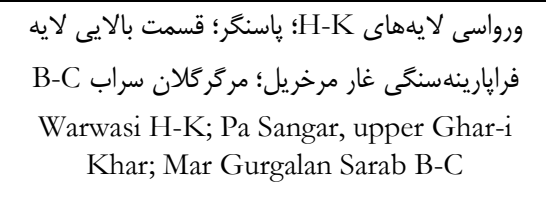 \\
\hline Earliest & $\begin{array}{c}\text { ريزتيغٔ دوفور؛ اشكال غيرهندسى ريزابزارها، حضور خراشندههاى ناخنى. } \\
\text { Dufour bladelets; no geometric forms of microliths; } \\
\text { presence of thumbnail scrapers }\end{array}$ & 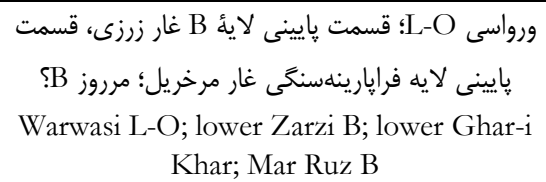 \\
\hline
\end{tabular}

r,r"اו (1S) هزار سال ييش ا شاره دارد. با درنظر خرفتن هانتىمتر رسوبات بدون سنسنجى در انتهاى فاز،

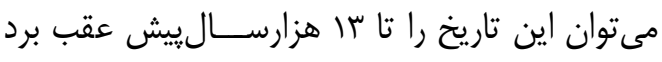

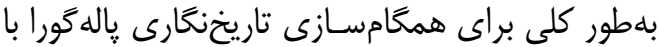

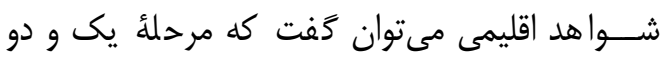
ترانشأ A با اواخربيشينأيخهالى (GS-2.1) همريوشانى

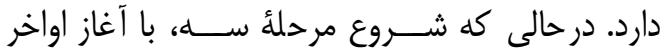

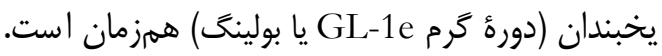
عدموجود سن سنجى در بيشتر قسمتهاى ر سوبات

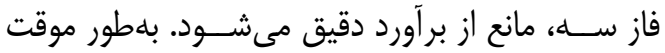

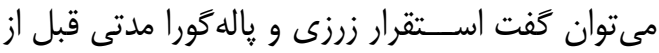

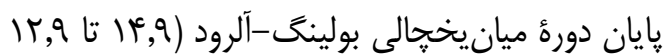

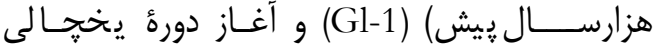

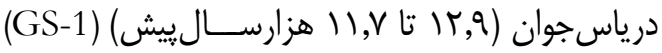
خاتمه يافته است [17]. (17).

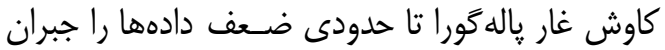

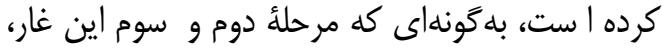

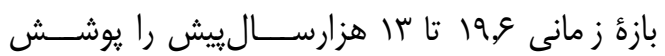
مىدهد. درنهايت، هنوز مرحلة يك كه شـامل آخرين بي شينأيخحالى ا ست، در هالهاى از ابهام قرار دارد. با لـان

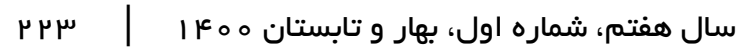

بررسى توالى و سن سنجىهاى پاله كورا كمى شايانى

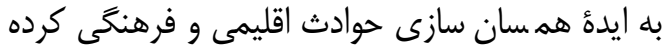

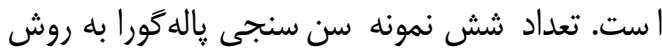

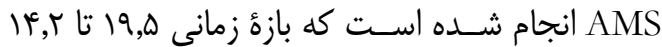

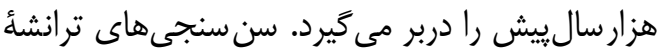
(PG2) A

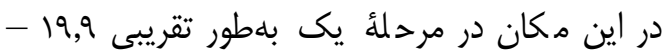

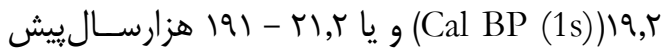

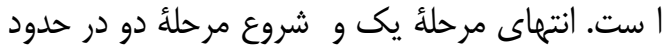

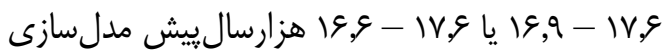

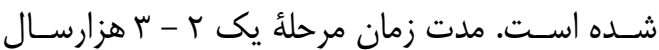

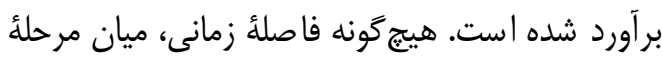
يكى و دو قابل مشـاهده نيسـت. انتهاى بالايى مرحلئ

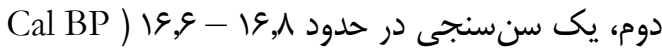

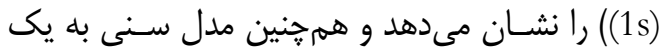

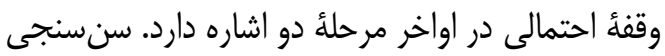

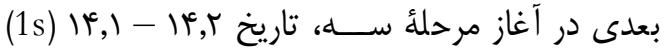
هزار سال ييش را زشان مىدهد. مرز ميان مرحلئ دو و

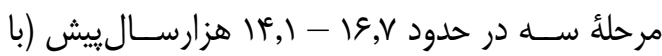

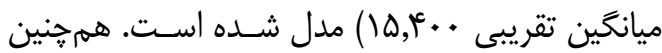
انتهاى فوقانى ترانشأ A به بايان توالى زرزى در حدود 
زرزى تُنين نيســتنـد. در هر دو منطقـه، ظهرور ريزابزارهاى هندسـى با اسـتفاده از فناورى ريزاسـكنه

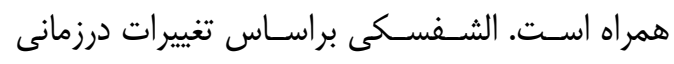

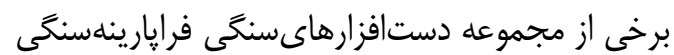

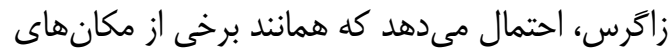

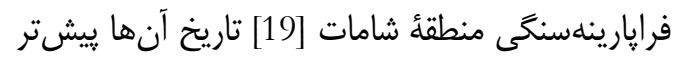
از ڤيا له گورا و ظهور آن ها حداكثر درحوالى آخرين

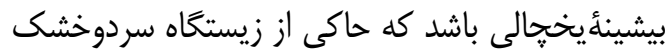

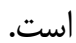
اســتفـاده از مواد آلى (اســتخوان) براى ابزار در استقرارهاى زرزى شناخته شده است. صدف دريايى

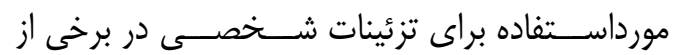

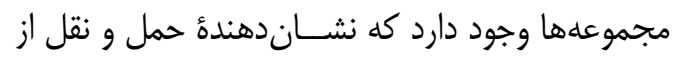
فواصــل دور يا شـبكههاى مبادلاتى اسـت. وسـايل

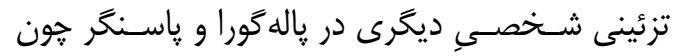

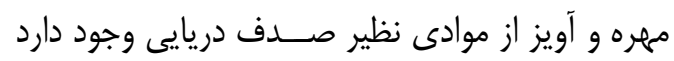

اولين شـــوا هد قطعى كه نشــــان مى هـد هد جوامع

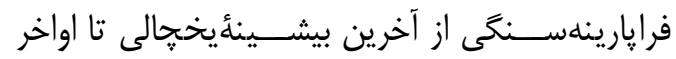

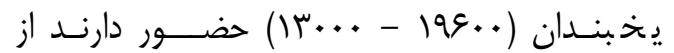
كاوشهاى جديد يالهَّورا بهدسـت آمد. نتايج پاله گورا

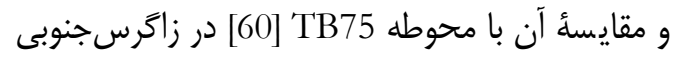

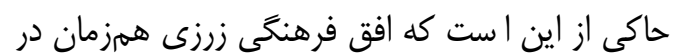

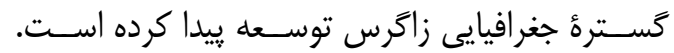
شواهد ياله كورا بهطور قطع زشان مىدهد كه تيهزارها و مناطق بالاد ست هالالحا صلخيز، دربر گيرنده طيف

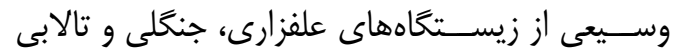
بودهاند كه بلطور گسـترده توســ جط جوامع زرزى مورد

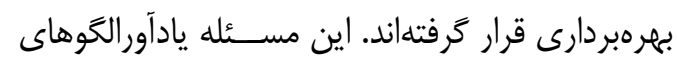

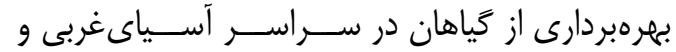

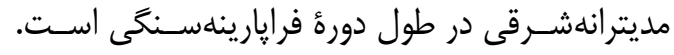

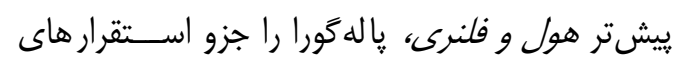
فصــلى دســـتهبندى كرده بودند كه با نتايج مطالعهُ بقاياى حيوانى كه محوطه را ايســتخاه شــكار معرفى دهـ

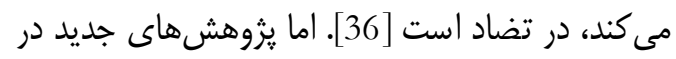

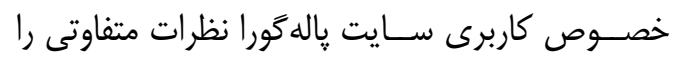

توجه به دادههاى بلدست آمده از قفقاز مىتوان اذعان دا شت كه زاگرس تا به امروز مطابقت بيشترى با اين

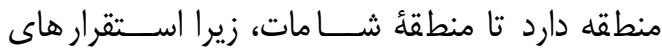

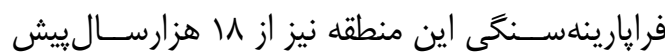
شروع مى شود. با درنظر گرفتن سن سنجىهاى قابل

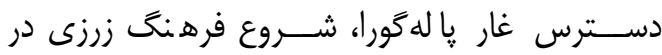
شمال غربزاگرس بهطور تقريبى از ها هزار سالييش درنظر گرفته شده است كه برخى از نويسندكان براى

شروع آن V ا هزارسال ييش را ييشنهاد دادهاند [17].

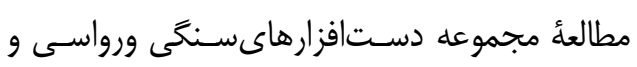
زرزى ذشاندهنده اين است كه اين دو مكان، قبل از

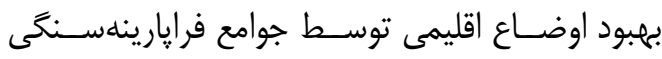
اشغال شده بودند، درحالى كه مكانى همانند شانهدرَ و و

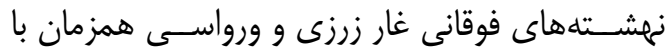

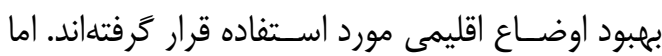
متأسفانه نبود سنسنجى دقيق در بيشتر مكانها، مانع از تشخيص دقيق تداوم استقرار از يارينهسنگَىنوين به ديه

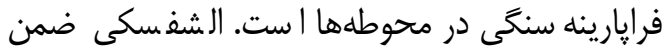
ا شاره به وجود تغييرات در طول زمان وروا سى، اذعان

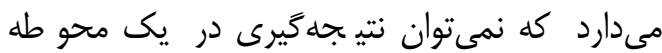
بدون سن سنجى را به كل منطقه تعميه داد. به اعتقاد وى، تغييرات گو نه هاى ابزارى در طول ز مان وجود

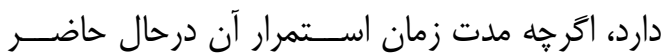

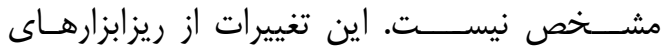
غيرهند سى به ريزابزارهاى هند سى را شامل مى شود كه بهطور عمده درابتدا مختلف|لا ضلاعها هـ ستتند، اما سيس شامل تعداد بيشترى از گونههاى ديخر ازجمله

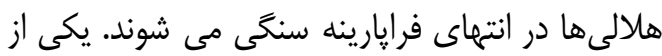

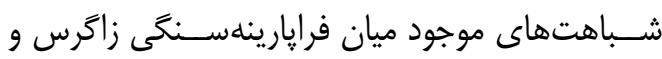
شامات تغيير د ستافزارهاى سنگَى از غيرهند سى به هندسـى اســت. درواقع مثلثى هاى مختلف الاضــلاع

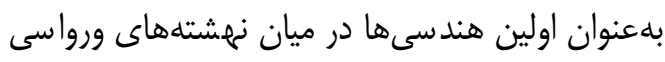
مستند شده است و بعدها هلالىها ظهور بييدا كردهاند. در شــامات مثلثىها يا ذوزنقهاى ها در مجموعههاى دهاى

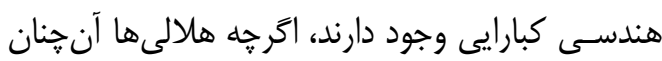
كه در ناتوفيان منطقة شامات غالب هـ ستند، در اواخر 
لايهنگارى ته در زمان كاوش و خه در زمان ثبت و ضــبط دادهها اســـ؛ به نحوى كه رســوبات اواخر

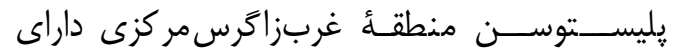
ويزگ هايى است كه نمىتواند ريز لايهها يا افقهايى

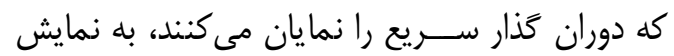

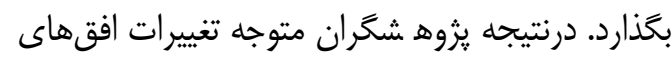

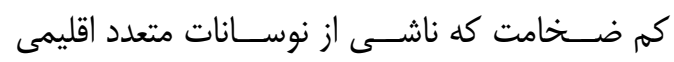
هستند، نمى شوند و در مقابل، تغييرات فرهنكى دوران

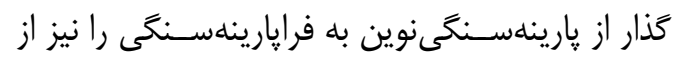

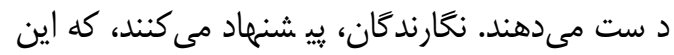
ضعف رابا كنترل بهتر و انجام سن سنجىهاى متعدد

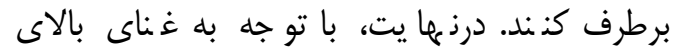

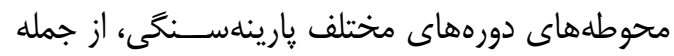

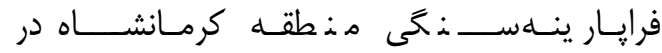

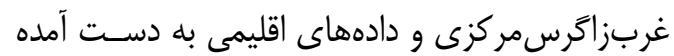

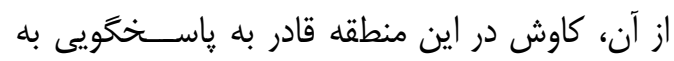

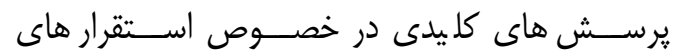
فرايارينهسنگى و تطبيق آن با دورههاى اقليمى است.

\section{يـىنوشت}

ا. منظور از عبارت فرايارينهســـــى در اين مقاله، ا ستقرارهاى نهايى دورة يلي ستو سن ا ست كه شار شامل

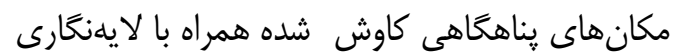

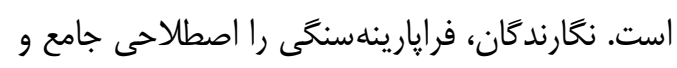

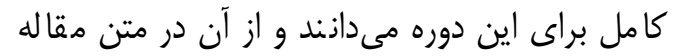

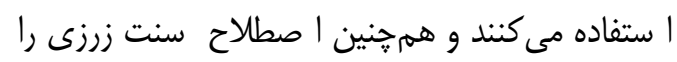

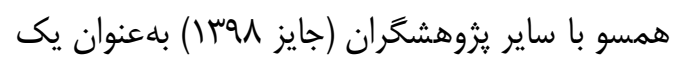

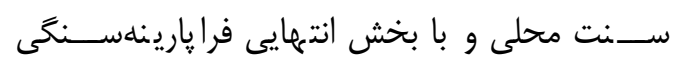
همزمان مى دانند و به كار مىبردند.

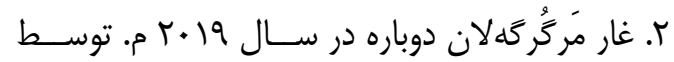
تيمى از دانشــاه رازى كرمانشـاه و كينهاكَدانمارى

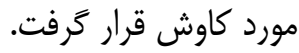

\section{تشكر و قدردانى}

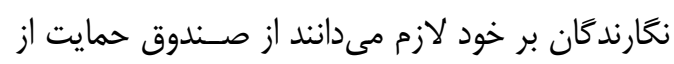
يثوهشــران و فناوران كشـور (INSF) براى حمايت
ارائه مى دهند. تنوع دادههاى جانورى اعم از حضــور

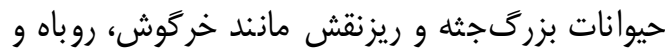

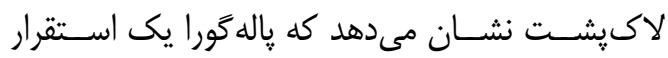
فصلى طولانى مدت است. همرجنين وجود توالى كامل تراش در مكان، زشان دهندة استقرار بلند مدت از هُ هند

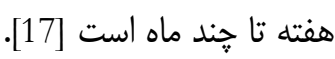

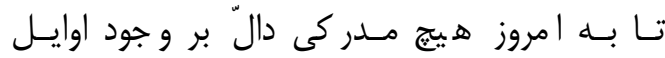
فرايارينه سنكى نظير آنجه كه در شامات وجود دارد، از

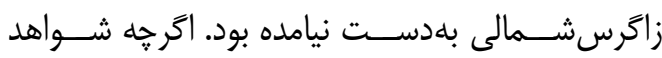

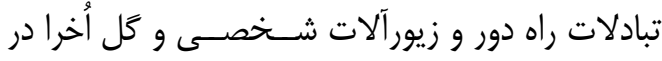

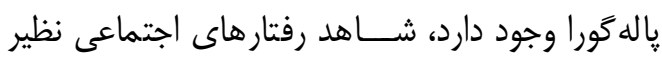
تدفين در اين مكان ني ستيه. در حالى كه در اوا سط و وارد

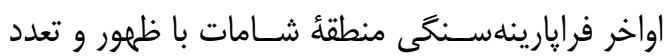
تدفينهاى انسانى مواجه هستيم [18]، بلنظر مى سد

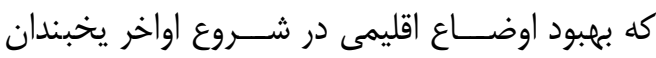

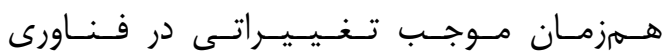

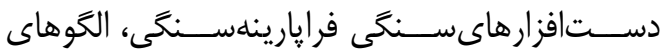

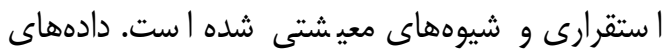

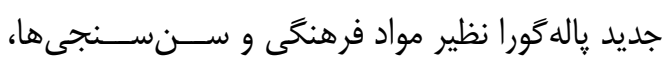
تعاريف كذشــاه شـامل كمبود منابع، اقليم نامطلوب و و انزواى فرهنكى و جغرافيايى را در مورد اســتقرارهاى

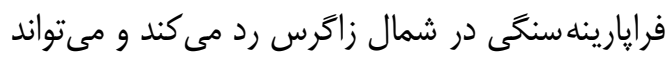

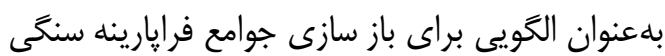

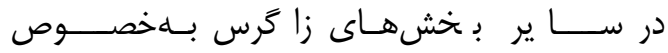

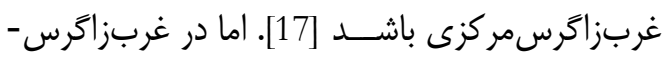

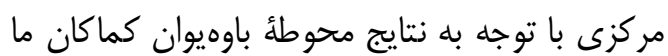

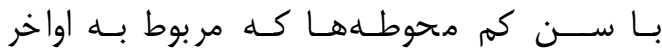

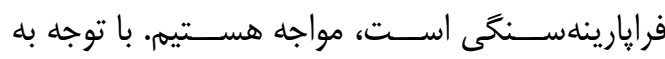

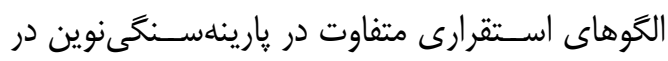

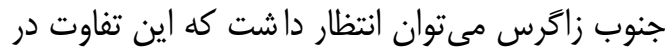

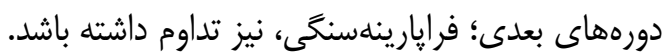

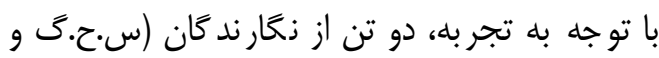
ن.ح) در جهار فصل كاوش در محوطؤ باوهيوان، معتقد

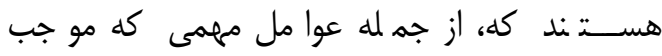

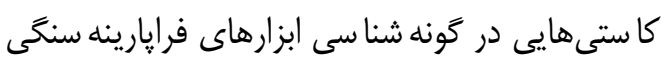

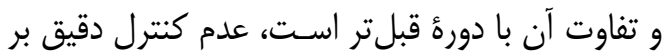




$$
\begin{aligned}
& \text { نظرات گَرانبهايشان و همجنين از خانمها زهرا خليلى، } \\
& \text { آذينحبيبزاده و فاطمه قاسمى سياس گزار هستيم. }
\end{aligned}
$$

\section{References}

[1] Olszewski D.I. Middle East: Epipaleolithic. In C. Smith (ed.), Encyclopedia of Global Archaeology, Springer International Publishing AG. Part of Springer Nature. 2018.

[2] Bar-Yosef O. Belfer-Cohen A. The Levantine Upper Pelaeolithic and Epipalaeolithic. In: Garcea, E.A.A. (Ed.), An Offprint from South-Eastern Mediterranean Peoples between 130,000 and 10,000 Years Ago. 2010; pp. 144-167.

[3] Jayez M. The Latest Lithic Industry of Zagros Pleistocene: Ambiguities and Contradictions in Zarzian Studies. Quaternary Journal of Iran. 2019; 5 (1), 79-104. [In Persion].

[جايز مز5ًان. زرزى: صنعتى سهل و ممتنع، ابهامات

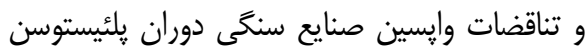
در زاكرس. فصلنامةٔ كواترنرى ايران. يوجاء؛ ه(1): $\left[.1+t^{4}-\mathrm{va}\right.$

[4] Maher L.A. Richter T. Stock J.T. The pre-natufian epipaleolithic: long-term behavioral trends in the levant. Evolutionary Anthropology: issues, news, and reviews. 2012; 21(2): 69-81.

[5] Garrod D.A.E. The Palaeolithic of Southern Kurdistan: excavations in the Caves of Zarzi and Hazar Merd. Bulletin of the American School of Prehistoric Research. 1930; 6: pp. 9-43.

[6] Garrod D.A.E. A New Mesolithic Industry: The Natufian of Palestine. Journal of the Royal Anthropological Society. 1932; 62: 257-269.

[7] Safaierad R. Azizi, G. Maghsoudi M. The role of changes in the large-scale atmospheric systems in the evolution of the late Pleistocene and Holocene climate of the Zagros Mountains. Quaternary Journal of Iran. 2018; 4(3): 253-271. [In Persion].

$$
\text { دالى اين ثيزوهش تشكر و قدردانى كنند. از سركارخانهم }
$$

$$
\begin{aligned}
& \text { [صفايىراد رضا، عزيزى قاسه، مقصودى مهران. نقش }
\end{aligned}
$$

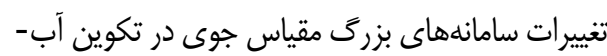

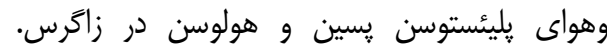

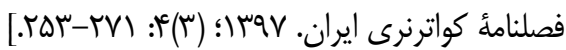

[8] Safaierad R. Azizi G. Mohammadi H. Alizadeh Lahijani H. Reconstructing the Holocene and Late-Pleistocene climate changes of the central Zagros using palynological evidence of the Hashilan wetland. Journal of Geography and Environmental Hazards. 2014; 3(11): 1-19. [In Persion]. ] صفايىراد رضا، عزيزى قاسه، محمدى حسين،

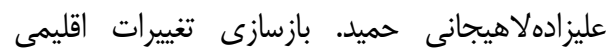

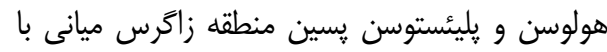

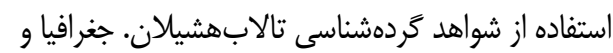

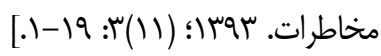

[9] Braidwood R.J. Howe B. Prehistoric Investigation in Iraqi Kurdestan, in Oriental Institute Studies in Ancient Oriental Civilization, vol. 31. University of Chicago Press. 1960.

[10] Olszewski D.I. The Late Zarzianian Occupation At Warawsi Rockshelter, Iran, In The Paleolithic Prehistory Of The Zagros-Taurus, edited By D.I. Olszewski And H.L.Dibble, Philadelphia: University Museum Symposium Series. 1993b; 5: 207-236.

[11] Young T.C. Smith P.E.L. Research in the prehistory of central western iran, Science. 1966; 155: 386-91.

[12] Heydari-Guran S. Benazzi, S. Talamo S. et al. The discovery of an in situ Neanderthal remain in the Bawa Yawan Rockshelter, West-Central Zagros Mountains, Kermanshah. PloS one. 2021; 16(8), e0253708.

[13] Hole F. Flannery V. The Prehistory of Southwest Iran: A Preliminary report, Proceedings of the Prehistoric Society.1967; 33: 147-206. 
[14] Mortensen P. Paleolithic and Epipaleolithic sites in the Holailan Valley northern Luristan, in the Paleolithic prehistory of the ZagrosTaurus, edited by D.I. Olszewski and H.l. dibble. Philadelphia: University Museum Symposium series. 1993; 5: 159-187.

[15] Solecki R.S. Prehistory in Shanidar valley, northern Iraq. Science. 1963; 139(3551):179-193.

[16] Wahida G.E. A reconsideration of the Upper Palaeolithic in the Zagros mountains. PhD thesis, University of Cambridge. 1975. Available from: https://idiscover.lib.cam.ac.uk/permal ink/f/t9gok8/44CAM_ALMA214327 11980003606

[17] Asouti E. Baird B. Kabukcu C. et al. The Zagros Epipalaeolithic revisited: New excavations and 14C dates from Palegawra cave in Iraqi Kudistan. PloS one. 2020; 15(9), e0239564.

[18] Maher L. A. Stock J. T. Finney S. et al. A unique human-fox burial from a preNatufian cemetery in the Levant (Jordan). PloS one. 2011; 6(1): e15815.

[19] Olszewski D.I. The Zarzian in the context of the Epipaleolithic Middle East. The International Journal of Humanities. 2012; 19(3):1-20.

[20] Olszewski D. I. Assessing patterning in the Upper Paleolithic and Epipaleolithic of Warwasi, Iran. International Journal of the Society of Iranian Archaeologists. 2017; 3 (5), pp. $1-12$.

[21] Golovanova L.V. Doronichev V.B. Cleghorn N.E. et al. The epipaleolithic of the Caucasus after the last glacial maximum. Quaternary International. 2014; 337: 189-224.

[22] Dansgaard W. Johnsen S.J. Clausen H.B. et al. Evidence for general instability of past climate from a 250 kyr ice-core record. Nature. 1993; 364(6434): 218-220.

[23] Heinrich H. Origin and consequences of cyclic ice rafting in the northeast Atlantic Ocean during the past 130,000 years. Quaternary research. 1988; 29(2):142-152.
[24] Belfer-Cohen A. Gorring-Morris N. Current issues in Levantine Upper Paleolithic Research. In: GorringMorris, N., Belfer-Cohen, A. (Eds.), More than Meets the Eye. Studies on Upper Paleolithic Diversity in the Near East. Oxbow Books. 2003; pp. 1-12.

[25] Bar-Yosef O. The Natufian culture in the Levant: threshold to the origins of agriculture. Evol Anthropol. 1998; 6:159-177.

[26] Thiagarajan N. Subhas A. V. Southon J. R. Eiler J. M. Adkins J. F. Abrupt preBølling-Allerød warming and circulation changes in the deep ocean. Nature. 2014; 511(7507): 75-78.

[27] Rasmussen S.O. Andersen K.K. Svensson A.M. et al. A new Greenland ice core chronology for the last glacial termination. Journal of Geophysical Research: Atmospheres.2006; 111(D6).

[28] Broecker W.S. Defining the boundaries of the Late-Glacial isotope episodes. Quaternary Research. 1992; 38(1): 135-138.

[29] Platt D. E. Haber M. Dagher-Kharrat M. B. et al. Mapping post-glacial expansions: the peopling of Southwest Asia. Scientific reports. 2017; 7(1): 1-10.

[30] Oberlander T.M. The Zagros streams. Syracuse Geographical Series 1. Syracuse, NY: Syracuse University Press. 1965.

[31] Heydari-Guran S. Ghasidian E. Late Pleistocene hominin settlement patterns and population dynamics in the Zagros Mountains: Kermanshah region. Archaeological Research in Asia. 2020; 21, 100161.

[32] Darabi H. Richter T. Mortensen P. Neolithization Process in the central Zagros. Documenta Praehistorica. 2019; 46: 44-57.

[33] Heydari-Guran S. Paleolithic landscapes of Iran, Bar International Series 2586. 2014.

[34] Wahida G. The re-excavation of Zarzi, 1971. Proc. Prehist. Soc. 1981; 47: 1940.

[35] Wahida G. The Zarzian industry of the Zagros mountains. In: Davies W, Charles R, editors. Dorothy Garrod and 
the progress of the Palaeolithic. Oxford: Oxbow. 1999; pp. 181-208.

[36] Turnbull P.F. Reed C.A. The fauna from the terminal Pleistocene of Palegawra Cave, a Zarzian occupation site in northeastern Iraq. Fieldiana. Anthropology. 1974; 63(3): 81-146.

[37] Turnbull P.F. The mammalian fauna of Warwasi rock shelter, west-central Iran. Fieldiana Geology. 1975; 33: 141-155.

[38] Olszewski D.I. Zarzian Microliths from Warwasi Rockshelter, Iran: Scalene Triangles as Arrow Components. In Hunting and Animal Exploitation in the Later Paleolithic and Mesolithic of Eurasia, G. Peterkin, H. Bricker, and P.D.C.: Archaeololgical Papers of the American Anthropological Society. 1993a; No. 4.

[39] Ghasidian E. The Upper Paleolithic Period in Iran and its Place in Southwestern Asia. NĀMVARNĀMEH; Papers in Honour of Massoud Azarnoush. Edited by: Hamid Fahimi and Karim Alizadeh. Tehran. Published by: IranNegar.2012; pp. 59-78. [In Persion].

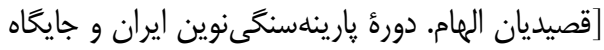
آن در جنوبغربآسيا، نشر ايران نغار، نامور نامه؛

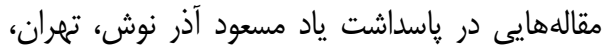

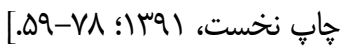

[40] Shidrang S. Biglari F. Bordes J.G. Jaubert J. Continuity and change in the late Pleistocene lithic industries of the Central Zagros: a typo-technological analysis of lithic assemblages from Ghar-e Khar cave, Bisotun, Iran. Archaeology, Ethnology \& Anthropology of Eurasia. 2016; 44(1): 27-38.

[41] Davoudi D. Abbasnejad Seresti R. The Paleolithic Survey of Holeylan, Central Zagros, Iran. International Journal of Humanitites. 2016; 23(3).

[42] Ghasidian E. Rethinking the Upper Palaeolithic of the Zagros Mountains. Paleo Anthropol. 2019; pp. 240-310.

[43] Shidrang S. The Middle to Upper Paleolithic Transition in the Zagros. The Middle and Upper
Paleolithic Archeology of the Levant and Beyond, Springer. 2017; pp. 133156.

[44] Wright H.E. Pleistocene glaciation in Kurdistan. E\&G Quaternary Science Journal. 1962; 12(1): 64-131.

[45] Van Zeist W. Bottema S. Palynological investigations in western Iran. Palaeohistoria.1977; 19, 19-85.

[46] Djamali M. de Beaulieu J. L. Shahhosseini M. et al. A late Pleistocene long pollen record from Lake Urmia, NW Iran. Quaternary Research. 2008; 69(3): 413-420.

[47] Djamali M. Ponel P. Delille T. et al. A 200,000-Year Record of the Brine Shrimp Artemia (Crustacea: Anostraca) Remains in Lake Urmia, NW Iran, International Journal of Aquatic Science. 2010; 1/1: 14-18.

[48] Stevens L. Djamali M. Valérie A.P. de Beaulieu J.L. Hydroclimatic variations over the last two glacial/interglacial cycles at lake Urmia, Iran, Journal of Paleolimnol. 2012; 47: 645-660.

[49] Vita-Finzi C. Recent earth movments. an introduction to neotectonids, London: Academic press. 1986.

[50] Brookes A.I. The physical geography, geomorphology and late Quaternary history of the Mahidasht project area, Qara Su basin central west Iran, Toronto: Royal Ontario Museum. 1989.

[51] Heydari Guran S.; Hariri N. The environmental changes and it's implication on early human occupations in the Kermanshah region during the late Quaternary. Ed: Yousf Moradi. Afarin nameh, Iranian Cultural Heritage Organization (ICHO) [In Persion]. 2019.

$$
\begin{aligned}
& \text { ]حيدرى ₹وران سامان حريرى نعمت. بازسازى محيطى }
\end{aligned}
$$

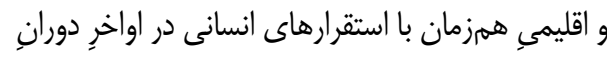

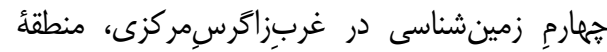

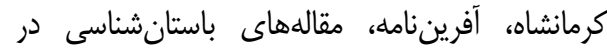

$$
\begin{aligned}
& \text { نكوداشت استاد مهدى رهبر به كوشش يوسف مراده، مرادي، }
\end{aligned}
$$

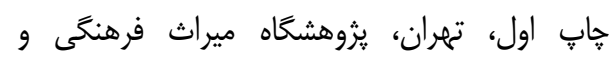

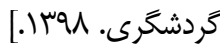

[52] Safaierad R. Matthews R. Dupont L. Djamali M. et al. Vegetation dynamics 
and climate history at the dawn of human settlement: multi-proxy paleoenvironmental evidence from Hashilan Wetland, western Iran. Quaternary Science Reviews (Under Review).

[53] Petraglia M.D. Groucutt H.S. Guagnin M. Breeze P.S. Boivin N. Human responses to climate and ecosystem change in ancient Arabia. Proceedings of the National Academy of Sciences. 2020; 117(15): 8263-8270.

[54] Safaierad R. Mohtadi M. Zolitschka B. Yokoyama Y. Vogt C. Schefuß E. Elevated dust depositions in West Asia linked to ocean-atmosphere shifts during North Atlantic cold events. Proceedings of the National Academy of Sciences. 2020; 117(31), 18272-18277.

[55]Jayez M. Shift in the Bladelet Production Process from Epipalaeolithic to Neolithic in the Izeh Plain of Kuzistan, Iran. Journal of Archaeological Studies. 2014; 5(2), 39 57.

[جايز، مزكان. تغيير خط سير توليد ريزتيغهها از

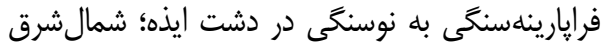

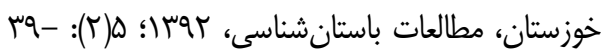

$[. \Delta \Lambda$

[56] Niknami K. Jayez M. Settlements of Izeh Plain in Stone Age: Characterization and Topographical
Analysis. Iranian Studies. 2012; 1(1), 57-80. [In Persion].

[نيكنامى كمال الدين جايز، مزَّان. محوطههاى عصر

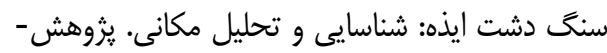

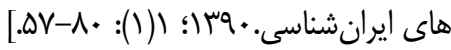

[57] Dashtizadeh A. Preliminary study of the Chashmeh Kazerun cave. Arseh (Journal of Kazerun Islamic Azad University). 2003; No. 1: 76-61.

[دشتى اده عبدالرضا. بررسى مقدماتى غارجشماسمساسان :

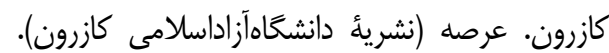

[S

[58] Niknami K.A. Jayez M. Spatial patterning of Epipalaeolithic-early neolithic site structure of Izeh Plain, southwestern Iran. In: Loannides, M., Addison, A., Georgopoulos, A., Kalisperis, L. (Eds.), VSSM2008Digital Heritage-Proceedings of the 14th International Conference on Virtual Systems and Multimedia, Limassol. 2008; pp. 139-145.

[59] Tsuneki A. Zeidi M. Tang-E Bolaghi, the iran-japan archaeological project for the sivand dam salvage area, ALSHARK3, university of tsukuba, studies for west asian archaeology. 2008.

[60] Ohnuma K. Lithic assemblages from TB75 and TB130. Tange Bolaghi: The IranJapan Archaeological Project for the Sivand Dam Salvage Area. 2008; pp. 85-120. 